\title{
Electrical Discharge Machining Non-Conductive Ceramics: Combination of Materials
}

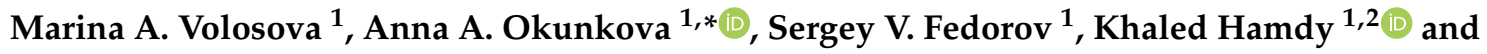 \\ Mariya A. Mikhailova ${ }^{1}$ \\ 1 Department of High-Efficiency Processing Technologies, Moscow State University of Technology STANKIN, \\ Vadkovskiy per. 3A, 127055 Moscow, Russia; m.volosova@stankin.ru (M.A.V.); \\ sv.fedorov@icloud.com (S.V.F.); eng_khaled2222@mu.edu.eg (K.H.); m.mikhailova@stankin.ru (M.A.M.) \\ 2 Production Engineering and Mechanical Design Department, Faculty of Engineering, Minia University, \\ Minia 61519, Egypt \\ * Correspondence: a.okunkova@stankin.ru; Tel.: +7-909-913-1207
}

Received: 24 April 2020; Accepted: 26 May 2020; Published: 28 May 2020

check for updates

\begin{abstract}
One of the promising processing methods for non-conductive structural and functional ceramics based on $\mathrm{ZrO}_{2}, \mathrm{Al}_{2} \mathrm{O}_{3}$, and $\mathrm{Si}_{3} \mathrm{~N}_{4}$ systems is electrical discharge machining with the assistance of an auxiliary electrode that can be presented in the form of conductive films with a thickness up to 4-10 $\mu \mathrm{m}$ or nanoparticles - granules, tubes, platelets, multidimensional particles added in the working zone as a free poured powder the proper concentration of which can be provided by ultrasound emission or by dielectric flows or as conductive additives in the structure of nanocomposites. However, the described experimental approaches did not reach the production market and industry. It is related mostly to the chaotic development of the knowledge and non-systematized data in the field when researchers often cannot ground their choice of the material for auxiliary electrodes, assisting powders, or nano additives or they cannot explain the nature of processes that were observed in the working tank during experiments when their results are not correlated to the measured specific electrical conductivity of the electrodes, particles, ceramic workpieces or nanocomposites but depends on something else. The proposed review includes data on the main electrophysical and chemical properties of the components in the presence of heat when the temperature in the interelectrode gap reaches $10,000{ }^{\circ} \mathrm{C}$, and the systematization of data on ceramic pressing methods, including spark plasma sintering, the chemical reactions that occur in the interelectrode gap during sublimation of primary (brass and copper) and auxiliary electrodes made of transition metals $\mathrm{Ti}, \mathrm{Cr}, \mathrm{Co}$, and carbon, auxiliary electrodes made of metals with low melting point $\mathrm{Zn}, \mathrm{Ag}, \mathrm{Au}, \mathrm{Al}$, assisting powder of oxide ceramics $\mathrm{TiO}_{2}, \mathrm{CeO}_{2}, \mathrm{SnO}_{2}$, ITO, conductive additives $\mathrm{Cu}, \mathrm{W}, \mathrm{TiC}, \mathrm{WC}$, and components of $\mathrm{Al}_{2} \mathrm{O}_{3}$ and $\mathrm{Zr}_{2} \mathrm{O}$ workpieces in interaction with the dielectric fluid - water and oil/kerosene medium.
\end{abstract}

Keywords: structural ceramic; oxide ceramic; $\mathrm{EDM} ; \mathrm{ZrO}_{2} ; \mathrm{Al}_{2} \mathrm{O}_{3}$; electrode; thin films; electrical conductivity; white layer; electro physics; chemical reactions; sublimation

\section{Introduction}

One of the widespread machining methods is electrical discharge machining (EDM) that allows producing parts regardless of physical and mechanical properties. The only usability condition for EDM is the electrical conductivity of the workpiece material: the higher specific electrical conductivity provides the higher material removal rate [1-3].

In addition, it is one of most precise machining methods as the diameter of the electrode-tool on EDM equipment can vary from 0.6 up to $0.05 \mathrm{~mm}$. The accuracy of electrode positioning on the industrial equipment under certain conditions can reach 1-2 $\mu \mathrm{m}(80-100 \mathrm{~nm}$ in some cases) when the 
achievable roughness $R a$ is about $0.4 \mu \mathrm{m}$ after roughing. It also allows removing significant volumes of material by a single pass of a wire tool. That can be a considerable advantage in the conditions of the tool industry in comparison with other machining methods based on the mechanical nature of removal.

The electrical discharge machining allows for obtaining complex spatial geometry with a slope of the generatrix up to $30^{\circ}$ relative to the Z-axis and making holes with an arcuate or spiral-shaped generatrix on die-sink equipment. The most modern machines are equipped with computer numerical control with additional rotary mechanisms for the workpiece fixture that allows moving both rotationally and indexally according to the developed program in full coordination with movements of other axes, expanding the available geometry to six axes (Figure 1).

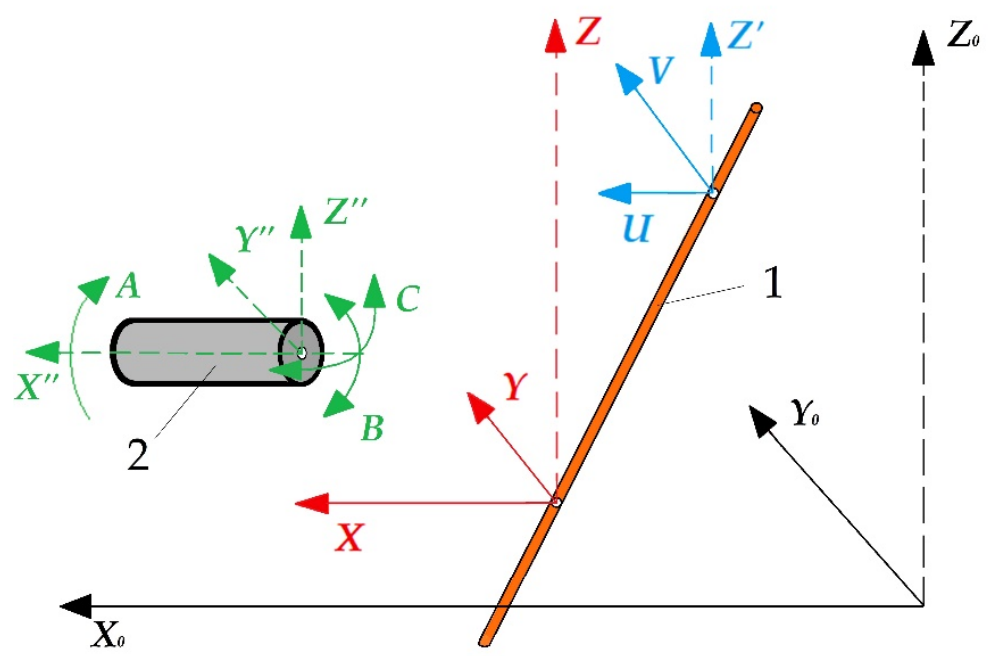

Figure 1. Additional rotary axes of wire electrical discharge machining: (1) is a tool, (2) is a part, $X_{0} Y_{0} Z_{0}$ is an absolute coordinate system of the machine, $X Y Z$ is a relative coordinate system of the lower wire attachment point, $U V Z^{\prime}$ is an auxiliary coordinate system of the upper wire attachment point, $X^{\prime \prime} Y^{\prime \prime} Z^{\prime \prime}$ is a relative coordinate system of the part, $A B C$ is an additional rotary axes.

The process of electrical erosion of the material consists of following stages:

- the initiation of an electric pulse in the interelectrode gap,

- the breakdown of the dielectric medium by a series of the discharge of pulses,

- the formation of a discharge channel with a temperature of more than $10,000{ }^{\circ} \mathrm{C}$ of a cloud of low-temperature plasma,

- the sublimation of material from the surface of the electrodes,

- the interruption of the pulses and washing off the cooled-down erosion products out of the interelectrode gap by dielectric medium flows,

- $\quad$ the restoration of dielectric tightness of the medium.

Due to the high temperatures that are fulminantly reached at the time of the formation of the discharge channel, the electrode material bypasses melting to the liquid phase. It sublimates directly from the solid phase to the condition of low-temperature gas plasma [4-7]. The ions of electrodes and fluid components interact with each other during subsequent pulses interruption and form sediment in the form of gases and droplets or dust that are washed out from the interelectrode gap by dielectric medium, which is, in most cases, water, oil, kerosene. The material of the electrodes and medium in the form of solid substances are partially adsorbed by the eroded surface of the electrodes that usually have a structure of nano-frames of the more resistant to high temperatures components.

For example, during processing steels in water, a subsurface layer of electrodes that often saturated with carbon and oxides is formed [8-10]. This layer is known as a recast or white layer. During machining stainless steel 12Kh18N10T (AISI 321), the nickel of the workpiece reacts with zinc of the 
brass electrode with the formation of the intermetallide accompanies processing by sparks and a black cloud of erosion dust [11,12]. At the same time, a natural oxide film is formed during processing fusible aluminum, copper, chrome, titanium, and their alloys [13-18]. When attempts to machine aluminum contained materials in oil or kerosene, the aluminum interacts with carbon from the organic medium in the presence of high temperatures when the oxide film is sublimated, with the formation of extremely dangerous aluminum carbide $\mathrm{Al}_{4} \mathrm{C}_{3}$ that may damage the filtration system of the equipment [19-22]. The experiments and chemical analyses of the samples showed that the components of the wire tool penetrate to a depth of $4-10 \mu \mathrm{m}$ (up to $35 \mu \mathrm{m}$ ). A thermal influence zone is observed at the same depth and characterized by the formation of an austenitic layer in steels $[4,10,11,18]$. The erosion products depose as well on the walls of the working tank and in filters. After electrical erosion, a crater-like surface topology on the surface of the workpiece is observed [23-26].

The dielectric properties of ceramics and nanoceramics, in combination with excellent physical and mechanical properties, limit their machinability - material removal volumes per tool pass, the complexity of the resulting geometry, and, accordingly, the scope of their potential application [27-30]. It restrains the growth of the economy and prevents the transition to the sixth technological paradigm associated with the concept of "nano", the development of innovative materials and technologies, and its introduction into the industry [31-36].

Today, there are three fundamental approaches to solving this problem (Figure 2). One of them is related to the introduction of a conducting secondary phase to the ceramic matrix of a composite or nanocomposite. It involves the use of powder metallurgy methods, including innovative hybrid sintering using assisting currents in graphite dies. The powder metallurgy methods of production conductive ceramics are known as industrial methods for creating composites from the mid-80s and continuously improves [37]. The idea of creating an electrically conductive ceramic nanocomposite has been developing since the late 80s [38], and many scientists have achieved remarkable results [21,22]. Still, more research is needed before the industrial introduction of this approach, since ceramics, when modified by conducting and non-conducting nanoparticles and platelets, do not always retain their original physical and mechanical properties, whiteness or even transparency, and after modification, even with confirmed improved properties, the material cannot always be electroerosively processed, even with proven conductivity much higher than the percolation threshold.

\section{Electrical discharge machining of non-conductive ceramics}

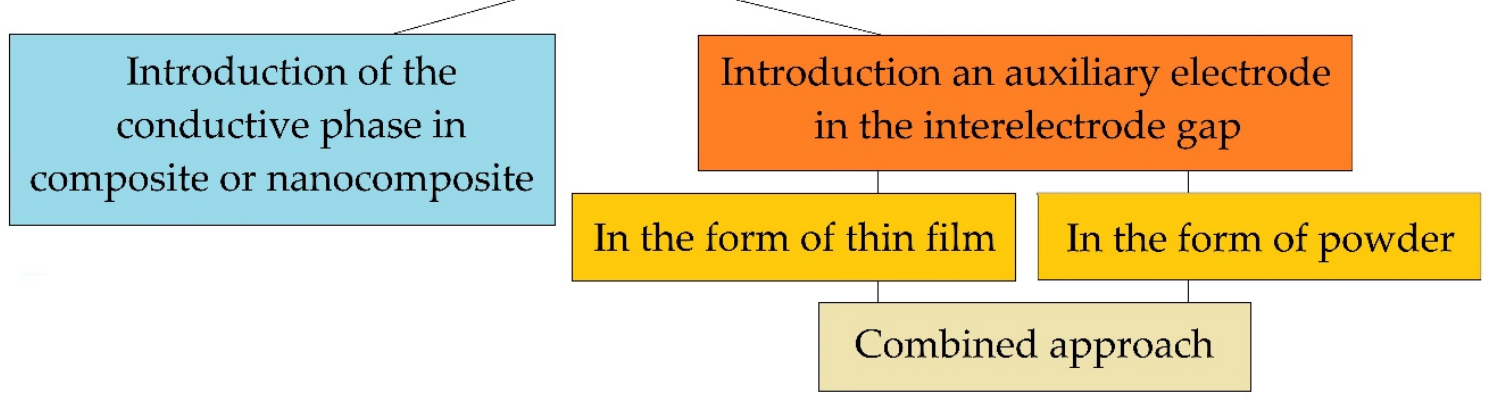

Figure 2. Electroerosive methods for processing non-conductive ceramics.

The second method for solving the problem of electrical discharge machining ceramics with high values of dielectric impermeability is the approach associated with the introduction of an auxiliary electrode in the interelectrode gap. The auxiliary electrode can be introduced in the form of a thin film produced of a conductive material (aluminum, copper, silver, etc.) on the surface of the dielectric workpiece, to which electric current discharges will be initiated. It is assumed that the erosion of the surface of the ceramic workpiece will be carried out simultaneously with the electrically conductive film. For the first time, the idea of introducing the auxiliary electrode was presented in the schematic 
diagram of electrical discharge machining dielectrics by soviet scientists [39]. Later similar experiments were carried out by many other scientists, and serious results were obtained - the ceramics were processed electroerosively to a depth of 1.5-2.0 $\mathrm{mm}$ [40]. In the described case, after the first operational iterations, when the film-electrode sublimates entirely, the question of reinitiation of current pulses in the interelectrode gap remains open.

The third method can be called an approach in which current discharges are directed to electrically conductive particles uniformly weighted in the volume of a liquid dielectric (water, oil, kerosene) in the interelectrode gap. In this case, it is necessary to monitor the constant concentration of conductive particles in the discharge gap. The first experiments to improve the dielectric constant of the working medium have been carried out since the creation of the method of electrical discharge machining materials by Professors Boris and Natalya Lazarenko [41-45]. The most outstanding works on changing the components of the working fluid during conductive materials processing appeared from the beginning of the 2000s [46]. It was related to the possibility of obtaining a finely dispersed substance and the ability to control the morphology of the used powders. The most relevant studies were obtained using carbon nanotubes and other forms of graphene in the discharge gap [4,47].

The direction of research related to the development of innovative methods of processing super-hard, heat- and wear-resistant materials without losing their physical and mechanical properties, with the possibility of obtaining complex spatial geometry and with minimal losses on material, on operating and auxiliary time, with minimum possible tool consumption, while maintaining high volumes of material removal by a pass of tool, is an extremely relevant task of modern science, as evidenced by multiple publications.

The novelty of the work is in the systematization of ceramic pressing methods, electrophysical and chemical properties of electrodes' and dielectrics' components in the presence of heat, data on possible interactions between components, suitable combinations of the materials for processing structural oxide ceramics as alumina and zirconia that can be applied for functional ceramics and nanocomposites.

This analytical study is designed to answer the question of why some materials should not be combined, why certain phenomena are observed during processing, why the workability of the workpiece is often not dependent on the electrical conductivity and temperature stability of the materials of the primary and auxiliary electrodes, assisting powder and conductive additives.

The tasks of the study include the analytical research on the conductivity of materials in the presence of heat and chemical composition of the subsurface layer of some materials, the investigation of physical properties of structural ceramics in the presence of heat and pressing methods, the sintering cycles under pressure and features of spark plasma sintering, main chemical interaction of alumina and zirconia components with materials of electrodes, assisting powder, additives, and working medium.

The analytical research was conducted, taking into account the basic principles of electrophysics and physical chemistry, the laws of the structures of substances, their structure and transformations, and available theoretical and practical information.

\section{Conductivity of Materials and Saturation of Components in Recast Layer}

All conductive materials are subject to electrical erosion to one degree or another. The group of materials to be electroerosively machined include aluminum, chromium, cobalt, copper, beryllium, molybdenum, nickel, niobium, titanium, tungsten, and their alloys including bronze and brass, high-temperature and magnetic cast alloys, cast iron and steels, graphite, hard alloys (carbide ceramics), titanium nitride and boride, conductive ceramic composites and nanocomposites, and some other materials (Figure 3). However, not only the specific electrical conductivity determines the possibility of using electrical discharge machining methods to process all practically conductive materials. The resistance to electrical erosion of metals is determined as well by a combination of thermophysical properties of materials such as a melting or sublimation point, heat capacity, density, structural and microstructural homogeneity, and thermal conductivity [34,48]. 


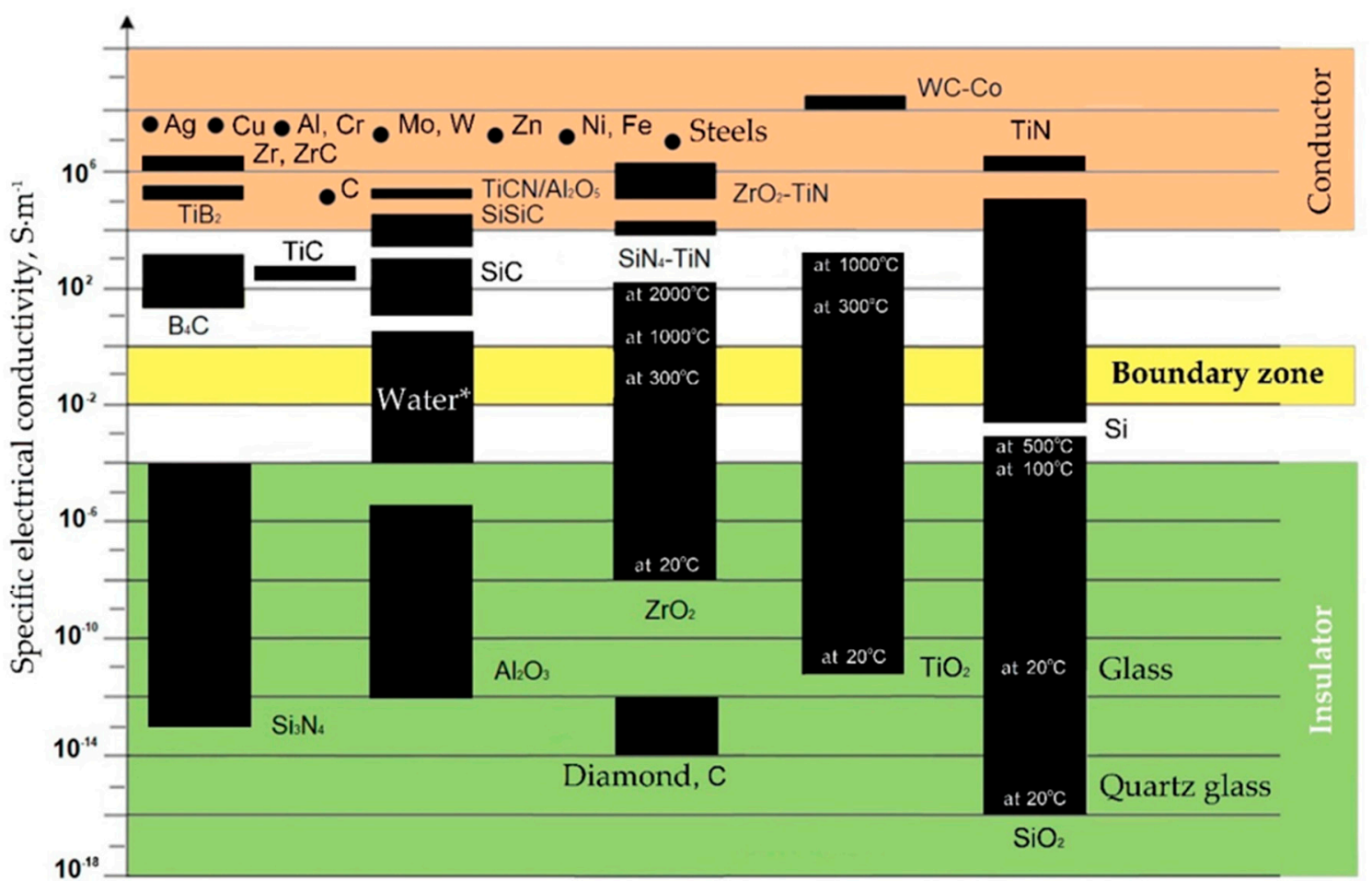

Figure 3. Specific electrical conductivity $(\varsigma)$ of some materials. $\left({ }^{*}\right.$ The electrical conductivity depends on impurities and suspensions, for distilled water is about $\left.10^{-5} \mathrm{~S} \cdot \mathrm{m}^{-1}\right)$.

Some dielectric materials change their electrical conductivity when heated and become conductors or semiconductors when metals have another tendency to the opposite phenomenon. It can have a positive effect on the electrical discharge machining a part whose chemical composition contains non-conductive at room temperature components. The conductivity is also affected by the presence of impurities in the material composition. In this case, conductive components increase the specific conductivity of the material, and non-conductive ones decrease. As can be seen, for materials such as carbon and silicon dioxide, the electrical conductivity often depends as well on the structure of the crystal lattice. Carbon the form of graphite calls a conductor when the carbon in the form of a diamond is an insulator, despite its anisotropic conductivity associated as well with the structure of the crystal lattice. Another example, the silicon dioxide in the crystalline form (silica glass) is a better dielectric than in the amorphous form of domestic glass. The same trend is observed for titanium dioxide.

One of the promising areas of research is the introduction into the interelectrode gap of a powder or nanosized powder. It can be some conductive metal or titanium dioxide, cerium dioxide, other ceramics in the powder phase $[49,50]$. In this case, the ceramics in the presence of heat would acquire conductive properties and provoke more dense discharges of pulses in processing main conductive material-usually metals and metal alloys such as extremely popular nickel alloys, construction and tool steels. The experiments showed that this approach gave a higher performance and improved the quality of machined surfaces related to the even topology.

Typically, the electroerosively machined surfaces have a matte appearance, similar to the surface fired by multiple shots. It contains disordered distributed tiny craters as a result of the material removal by separate discharges. The surface structure with the presence of craters and tubercles can be a favorable indicator for the retention of lubricants in the mechanisms and the formation of working cavities of injection molds. This type of surface is called "shagreen leather" [46]. It is easily distinguishable on any molded plastic products, mainly on computer and television case products, but also in the products for the transportation and sale of foods and drinks, toys for outdoor games.

There remains a layer of adsorbed substance, consisting mainly of components of the electrode-part and sometimes of components sublimated from the electrode-tool and decay products of the dielectric 
medium on the electroerosively machined surfaces. Mostly carbides are formed during processing in the organic dielectric as oil or kerosene and oxides during processing in deionized water $[13,14,19,26]$. The carbides are formed as well from the composition of steel during processing steels, as carbon is one of the most refractory materials. It counts as well for other alloys and complex materials when refractory components form the recast or white layer [11,14,46,49-58]. In the case of processing ceramic composites and nanocomposites, the surface layer is saturated with low-melting components in a nano-frame of refractory components $[4,29,52]$. It was observed that this recast or white layer is more hard and brittle than the main material of the workpiece. The subsurface layer can be easily distinguishable on cross-sections of steels, nanocomposites based on oxide ceramics, other materials and alloys using scanning electron microscopy (Figure 4). In the case of machining steels, carbon saturated layer has a thickness of 2.5-50 $\mu \mathrm{m}$. It does not exceed $4-10 \mu \mathrm{m}$ for pure $99 \%$ chromium. The recast layer is considered favorable for shaping the cavities of injection molds. In cases where high fatigue strength of the product is required, the white layer can be removed mechanically or electrochemically [51].

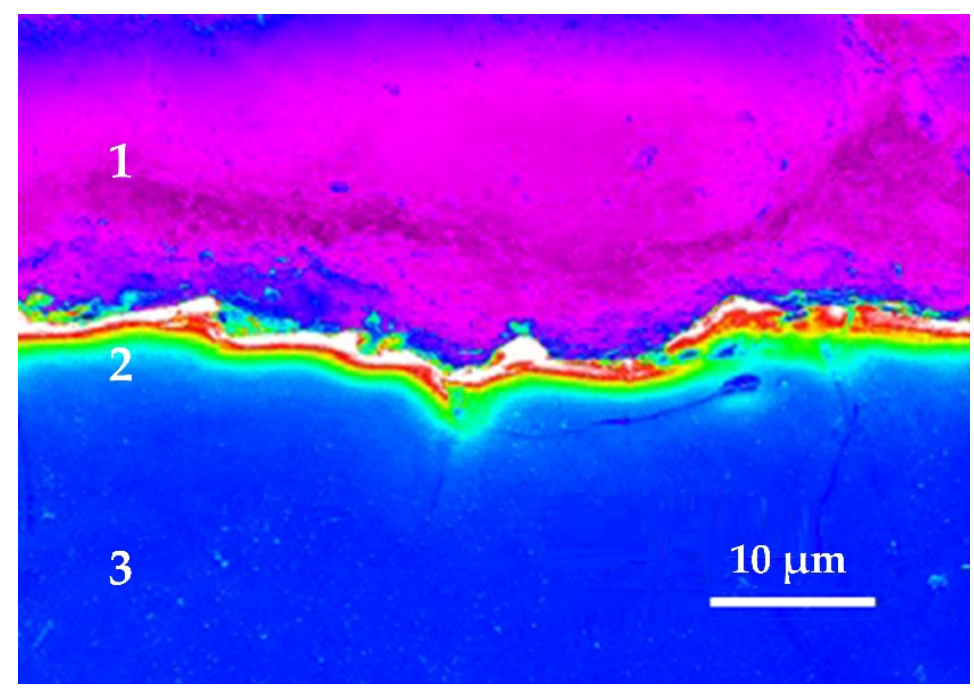

Figure 4. White layer obtained by electric discharge machining $99.9 \%$ pure chromium by a brass-wire electrode in a water medium: (1) is an epoxy resin that contains a sample for SEM analysis, (2) is a white layer of thermal exposure, a saturated component wire electrode-copper and zinc, (3) is a cut of the machined part made of chromium.

Obviously, the white layer and the erosion products are formed from the components of ceramics, dielectric medium, and auxiliary electrode during processing ceramics, the components of the primary phase and conductive additives of ceramic composites and nanocomposites also interact with other components in processing.

In some cases, the formed erosion products may have properties incompatible with the concept of safety-toxic or explosive gas or reactive sediment. Therefore, it is necessary to do carefully analyze the composition of all used main and auxiliary materials in the interelectrode gap, especially before designing the processing conditions for new materials. 


\section{Properties of Structural Ceramics in the Presence of Heat and Pressing Methods}

The ceramics are non-metallic and non-organic materials based on crystal compounds of non-metals and metals synthesized and consolidated by various methods to impart specific properties and geometry. At the same time, ceramics is a group of phase-sensitive materials-the properties of ceramics with a similar chemical compound may significantly differ depending on precursors, methods and technology parameters, structure, and phase composition of sintered materials, intermediate processing methods, surface quality, properties estimation methods, exploitation conditions.

The hard-to-melt compounds, which form the basis of structural ceramics, are characterized by low operational ability; in other words, they are difficult in forming blanks, sintering to high-density values, and processing to the required dimensions.

All used ceramics can be divided into structural and functional types. In this context, the structural ceramics provide the integrity and load-bearing capacity of the designs of various products, when physical and mechanical properties are of primary importance, when functional ceramics are aimed at specialized products and devices.

Although WC-Co system cermets still dominate the market of technical ceramics, some oxide ceramics can become a proper alternative in many production areas in the coming years [59-61]. Ceramic cutting tools based on oxide ceramics have gained popularity due to their ability to work in extreme conditions, when high wear resistance, hardness, and low chemical activity are required under operating conditions $[62,63]$. However, the scope of oxide ceramics as a structural material is still limited due to the low fracture toughness [64-66]. Cracks easily spread and often lead to uncontrolled fracture of specimens $[67,68]$.

There are various methods for improving the mechanical properties of oxide ceramic parts. For example, as was mentioned, the ability to reinforce $\mathrm{Al}_{2} \mathrm{O}_{3}, \mathrm{ZrO}_{2}$ by adding secondary phases made of carbide or nitride ceramics, metals, intermetallic compounds, or other materials to the ceramic matrix of composites or nanocomposites. The secondary phase in the form of powders and tubes, nano or micro platelets and fibers is helpful to increase strength and fracture toughness of ceramic matrix composites $[69,70]$. These methods have proven to be effective as experimental and innovative for increasing the properties of oxide ceramics as reinforced zirconia with $\mathrm{Ti}[\mathrm{C}, \mathrm{N}]$ or $\mathrm{CeO}_{2}$ particles or reinforced alumina with multidimensional ceramic particles of $\mathrm{SiC}, \mathrm{WC}, \mathrm{TiC}$, TiN [27,28,59,60,71-73].

Silicon nitride is also one of the most promising materials for critical applications because of its high strength, thermal conductivity, low coefficient of thermal expansion, high resistance to thermal shock, which are superior to oxide ceramics. Silicon nitride and Silicon alumina nitride (SiAlON) can be called the most suitable ceramics for machining superalloys. At the same time, silicon nitride $\mathrm{Si}_{3} \mathrm{~N}_{4}$ has low hardness and wear resistance [74,75].

There is a few ceramics compaction technique, sometimes combined with sintering that influences the physical and mechanical properties of blanks [76,77]. Cold static pressing is a unique and straightforward technique for pressing the products of different shapes from any compounds that allow realizing it in the conditions of mass production [78]. However, it does not allow distributing the properties of the product in the volume evenly.

The hot-pressing method solves the problems of the cold pressing method partly since it provides better strength characteristics of the products, the minimum tolerances on the size of the workpieces, reduces of sintering time due to the combination of the pressing and sintering processes. The disadvantage of this method is the rapid wear of the molds and the low productivity of the process $[79,80]$. Applying a hot-pressing method improves the strength and macrostructural characteristics of the workpieces. However, ferroelectric and ferromagnetic properties deteriorate. That can be a disadvantage for electroceramics but an advantage for structural ceramics. Significant grain growth in zirconia ceramics made by hot-pressing can be observed. In addition, ceramic ferroelectrics obtained by hot-pressing, in comparison with conventional annealing, deteriorate performance due to the presence of residual stresses and violation of stoichiometry of the molar masses of the components. 
The hot-pressing method allows obtaining products with a more uniform distribution of density throughout the volume and effective in the production of some types of nanoceramics with superplasticity at elevated temperatures, which can significantly reduce the cost of products due to the elimination of machining. However, the use of the hot-pressing method is limited by high demands on the material of the mold, which must be inert concerning the pressed powders at elevated temperatures, heat-resistant, not having the property of superplasticity, economical.

Hot isostatic pressing is one of the varieties of the method that implemented using various techniques based on the use of elastic media-liquids, gases, polyurethane, etc. by a disposable mold, which avoids the friction forces of the powder granules on the stationary parts of the mold, which is indispensable for the conditions of mass production [81,82].

Other pressing methods are usually aimed at eliminating the drawbacks of previous methods, for example, dynamic pressing methods as isothermal stamping, magnetic pulse (with amplitude up to $5 \mathrm{GPa}$, when the pressure of conventional pressing methods does not exceed $1 \mathrm{GPa}$ ), explosive, hydrodynamic, impact or shock (up to $35 \mathrm{GPa}$ ), shear compaction, electrical consolidation, various ultrasound vibration moldings (in the range of $16-22 \mathrm{kHz}$ ), pressureless packing [83-89]. They are aimed at improving the density of the workpieces and more uniform density distribution, relieving stresses, preventing grain growth during subsequent sintering. Their use is always limited by the maximum achievable dimensions of the workpiece, the need to use methods of preliminary destruction of agglomerates, and the removal of sorbed gases.

In addition, when choosing ceramics, designers are often guided not only by their physical and mechanical properties but also by their appearance, which is extremely important for some applications and depends not only on the composition of ceramics but also on the methods of their pressing and sintering [77]. For example, in the production of samples by hot-pressing, preforms are predominantly black-gray, while white is predominant in ceramics obtained using cold pressing methods. That correlates to the fundamentals of physical chemistry when other chemical transformations occur in the presence of heat $[4,14,29]$.

The relationship of the basic physical and mechanical properties of some materials to develop requirements for the material is shown in Figure 5. It should be noted that in the presented figure, the range of parameter values for $\mathrm{Al}_{2} \mathrm{O}_{3}$ and $\mathrm{ZrO}_{2}$ refers to samples obtained by isostatic pressing from powder, and Elbor refers to any trademarks of cubic boron nitride (c-BN).

It should be noted that oxide ceramics as alumina $\mathrm{Al}_{2} \mathrm{O}_{3}$ and zirconia $\mathrm{ZrO}_{2}$ among the mentioned above properties including low electrical conductivity at room temperatures show other highly relevant for some application properties as chemical inertness even at elevated temperatures or in the presence of an oxidizing agent, hot hardness (or redness, high hardness, and wear resistance to temperatures of red heat), low coefficient of thermal conductivity, and low coefficient of thermal expansion in comparison with more widespread construction materials (Table 1).

As can be seen, despite the quite high thermal conductivity and hardness and low thermal expansion coefficient, alumina $\mathrm{Al}_{2} \mathrm{O}_{3}$ has lower flexural strength and crack growth resistance in comparison with zirconia $\mathrm{ZrO}_{2}$.

It should be noted that electrical conductivity of ceramics that contain vitreous (glassy) phase (amorphous) increases significantly with an increase in temperatures since the concentration and mobility of charge carriers are exponentially dependent on temperature $(t)$ :

$$
\begin{gathered}
\varsigma=\varsigma_{0} e^{\beta t}, \\
\chi=\chi_{0} e^{-\beta t},
\end{gathered}
$$

where $\varsigma_{0}$ and $\chi_{0}$ are values of specific electrical conductivity and volume resistivity at $0{ }^{\circ} \mathrm{C}, \beta$ is the temperature coefficient. 


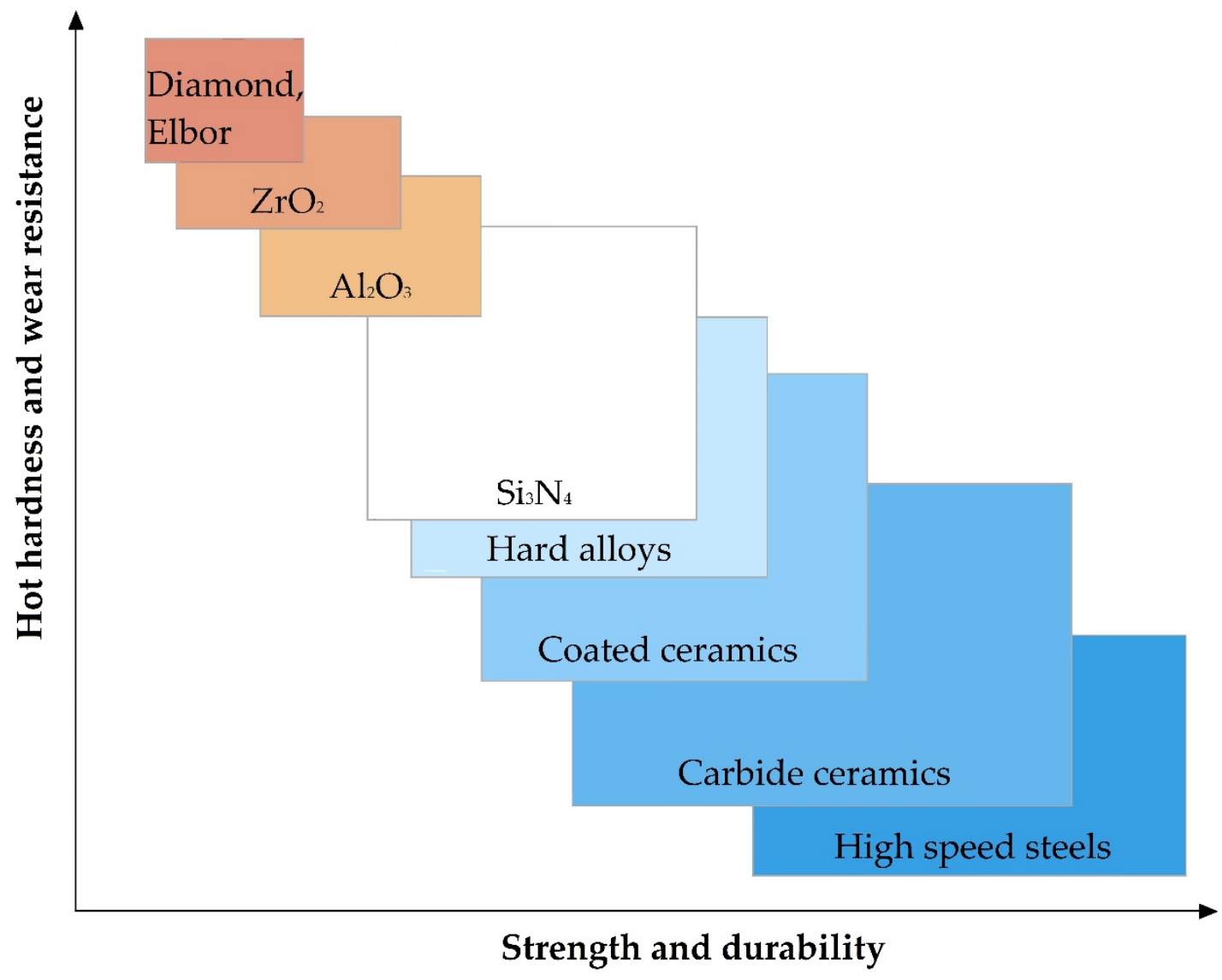

Figure 5. The relationship of the basic physical and mechanical parameters for some materials.

Table 1. The main properties of some materials [90-94].

\begin{tabular}{|c|c|c|c|c|}
\hline $\begin{array}{c}\text { Physical, } \\
\text { Mechanical and } \\
\text { Electro Properties }\end{array}$ & $\mathrm{Al}_{2} \mathrm{O}_{3}$ & $\mathrm{ZrO}_{2}$ & $\mathrm{Si}_{3} \mathrm{~N}_{4}$ & Stainless Steel * \\
\hline Density $(\rho), \mathrm{g} / \mathrm{cm}^{3}$ & $3.8-4.0$ & $6.0-6.05$ & $2.37-3.25$ & $7.6-7.95$ \\
\hline Melting point, ${ }^{\circ} \mathrm{C}$ & 2044 & 2715 & 1900 & 1420 \\
\hline $\begin{array}{l}\text { Flexural strength } \\
(\sigma), \mathrm{MPa}\end{array}$ & $300-350$ & $750-1050$ & $650-800$ & $110-550$ \\
\hline $\begin{array}{l}\text { Vickers hardness } \\
(H V), \mathrm{GPa}\end{array}$ & $19-21$ & $12-13$ & $16-19.6$ & 0.129 \\
\hline $\begin{array}{l}\text { Fracture strength } \\
\quad\left(k_{1 c}\right), \mathrm{Pa} \cdot \mathrm{m}^{\frac{1}{2}}\end{array}$ & $3.0-3.5$ & $8.0-10.0$ & $6.5-7.2$ & - \\
\hline $\begin{array}{c}\text { Thermal } \\
\text { conductivity }(k), \\
\mathrm{W} \cdot \mathrm{m}^{-1} \cdot \mathrm{K}^{-1}\end{array}$ & $25-30$ & $2-3$ & $10-43$ & $30-45$ \\
\hline $\begin{array}{l}\text { Thermal expansion } \\
\text { coefficient }(\alpha) \text {, } \\
10^{-6} \cdot \mathrm{K}^{-1}\end{array}$ & $8.0-9.0$ & $10.0-11.0$ & $1.4-3.7$ & $9.9-17.3$ \\
\hline
\end{tabular}


Table 1. Cont.

\begin{tabular}{|c|c|c|c|c|}
\hline $\begin{array}{c}\text { Physical, } \\
\text { Mechanical and } \\
\text { Electro Properties }\end{array}$ & $\mathrm{Al}_{2} \mathrm{O}_{3}$ & $\mathrm{ZrO}_{2}$ & $\mathrm{Si}_{3} \mathrm{~N}_{4}$ & Stainless Steel * \\
\hline $\begin{array}{c}\text { Dielectric } \\
\text { permittivity }(\varepsilon), \\
\text { F/m }\end{array}$ & $9.5-10$ & $\sim 25$ & $\sim 7-7.5$ & - \\
\hline $\begin{array}{l}\text { Specific electrical } \\
\text { conductivity }\left(\varsigma_{20^{\circ}}\right) \\
\text { at room } \\
\text { temperatures } \\
\left(20^{\circ} \mathrm{C}\right), \mathrm{S} \cdot \mathrm{m}^{-1}\end{array}$ & $\begin{array}{c}1.0 \times 10^{-10}-1.0 \times \\
10^{-12}\end{array}$ & $\begin{array}{c}1.0 \times 10^{-6}-1.0 \times \\
10^{-8}\end{array}$ & $\begin{array}{c}1.0 \times 10^{-4}-1.0 \times \\
10^{-13}, \text { minimal } \\
\text { volume electrical } \\
\text { resistivity }(\chi, \Omega \cdot \mathrm{m}) \\
19 \text { at } 20^{\circ} \mathrm{C}\end{array}$ & $0.5-0.8 \times 10^{7}$ \\
\hline $\begin{array}{l}\text { Specific electrical } \\
\text { conductivity } \\
\left(\varsigma 1000^{\circ}\right) \text { in the } \\
\text { presence of high } \\
\text { temperatures } \\
\left(1000^{\circ} \mathrm{C}\right), \mathrm{S} \cdot \mathrm{m}^{-1}\end{array}$ & $\begin{array}{l}\text { No more than } \\
1.0 \times 10^{-6}, \\
\text { electrical } \\
\text { conductivity is } \\
\text { higher in powder } \\
\text { materials due to } \\
\text { impurities, at low } \\
\text { pressures - n-type } \\
\text { semiconductor }\end{array}$ & $1.0-10.0$ & $\begin{array}{l}\text { Workability up to } \\
1350^{\circ} \mathrm{C} \text {, min } \\
\text { volume electrical } \\
\text { resistivity }(\chi, \Omega \cdot \mathrm{m}) \\
15 \text { at } 200^{\circ} \mathrm{C}, 12 \text { at } \\
600{ }^{\circ} \mathrm{C} \text {; that } \\
\text { corresponds to } \\
6.7 \times 10^{-2} \text { and } \\
8.3 \times 10^{-2}[95-97]\end{array}$ & $0.81-0.86 \times 10^{-10}$ \\
\hline
\end{tabular}

* Given for reference [98,99].

The electrical conductivity of crystalline ceramics (for titanium(IV) dioxide $\mathrm{TiO}_{2}$, it matches the form of anatase-metastable mineral), changes slower and retain quite low values at very high temperatures.

It should be noted that the porous ceramics significantly increases specific electrical conductivity in the presence of moisture, even in the smallest quantities [95-97].

The study devoted to the evaluation of ceramics workability by electrical discharge machining with an auxiliary electrode [100] describes the properties of non-conductive ceramics as $\mathrm{ZrO}_{2}, \mathrm{Si}_{3} \mathrm{~N}_{4}$, and $\mathrm{SiC}$ subjected to electrical discharge machining. The Vickers hardness (HV0.3), surface roughness $(S q)$, and flexural strength of samples were compared before and after machining since the use of the methods based on electrical erosion of the materials traditionally causes a decrease in these parameters due to the nature of the material destruction and the zone of thermal influence (or heat-affected zone, HAZ). It was found that the effect shows changes three times higher than the parameters before processing for $\mathrm{ZrO}_{2}$ samples, and twice for in $\mathrm{Si}_{3} \mathrm{~N}_{4}$. It can correlate with specific electrical conductivity in the presence of high temperatures $\left(\varsigma^{1000^{\circ}}\right)$, thermal expansion coefficient $(\alpha)$, and chemical transactions of components that occurred in the presence of heat.

\section{Features of Structural Ceramics Sintering}

The ceramics in the form of billets obtained by powder pressing and sintering are usually processed by grinding using abrasive materials or solid tools made of technical diamond or c-BN to give them a more functional shape depending on their applications [6,101-105]. Processing ceramics of complex shapes using traditional processing methods is a complicated and time-consuming process due to their exceptional physical and mechanical properties.

The technological process of powder metallurgy for ceramic sintering consists of four main stages: production of powders, their mixing and homogenizing, pressing or molding, and subsequent sintering [106-112]. In all similar conditions, the method of powder compaction of billets often determines the properties of the final product and plays a decisive role in the formation of the internal structure as uniformity, absence of pores, and cracks [113-115]. Forming billets is often carried out by cold pressing under high working pressure up to $1000 \mathrm{MPa}$ in metal dies of a press that is oriented vertically. A mixture of powders is free-poured into the cavity of the dies between the upper and lower 
punches or several punches in the case of production with several transitions [116]. The stroke of the lower punch controls the dosage volume. The formed workpiece is pushed out of the cavity of the lower punch. For molding, specialized press equipment with mechanical, hydraulic, or pneumatic drives is used. The resulting billet has the dimensions and shape of the final product and the strength is sufficient for unloading and transporting the pre-form into the furnace for subsequent sintering. The workpiece is sintered to increase its strength and ductility. For the production of high-precision parts, sintering is carried out in furnaces with a reducing (hydrogen, dissociated ammonia) or protective (nitrogen, argon, endothermic gas) atmosphere. Forming is also often carried out using the molding method in combination with sintering by electric current pulses [117].

Traditional sintering methods based on an isostatic process form a ceramic preform in the presence of high temperatures (up to $1100^{\circ} \mathrm{C}$ ). The sintering process can take $1-5 \mathrm{~h}$ to obtain a denser structure of the workpiece. At the same time, it is believed that high temperature and prolonged sintering time lead to undesirable grain growth, which may adversely affect the operational properties of the material $[38,118,119]$. Some chemical transactions can occur with impurities in the ceramic powder during sintering. It leads to the formation of a precipitate that has properties exceeded main material properties and gas evolution. Thus, excessive porosity can be obtained at high temperatures of sintering, which obviously also reduces the physical and mechanical properties of the ceramics.

Spark plasma sintering (SPS) is often used as an alternative method of consolidating powder billets to reduce sintering temperatures. The use of this technology in combination with the use of additional currents facilitates, the rapid consolidation of the powder, makes it possible to produce sufficiently dense ceramic composites and nanocomposites, and prevents grain growth [120-122]. The technology also offers significant advantages, such as a faster and shorter sintering time compared to conventional methods of forming powder billets, which is primarily associated with the complex effect of mechanical pressure on the billet and electrical impulses during processing [123-125].

Spark plasma sintering is an advanced technology with high potential for material processing. Its principles are similar to hot-pressing and differ in the source of heat. SPS uses pulsed direct current (DC), which is passed through the dies and acts in such a way as a heat source that corresponds to the Joule effect. It is used to minimize grain growth and obtain a dense nanostructured material.

A machine for spark plasma sintering consists of a press sintering machine with a vertical uniaxial pressurization mechanism, specially designed electrodes with adjustable water pumping, a cooler, a water-cooled vacuum chamber, a vacuum/air control mechanism, an argon-gas atmosphere control mechanism, a DC pulse generator, a water cooling control unit, a control unit for the position of the upper punch along the Z-axis, a temperature measuring unit (Figure 6).

During sintering, the compacted powder is compressed between the die and punches to which the electrodes are connected. After, the spark discharge is supplied, with the help of which high temperatures are obtained. It leads to thermal and electrolytic diffusion between the powder particles that depend on their turn on the electrical properties of the powder material in the presence of heat. Sintering occurs in the process at temperatures between 1000 and $2500{ }^{\circ} \mathrm{C}$. The heat distribution and the temperature difference between the core and the edges of the sintered billet are determined by the thermal conductivity of the billet material, which, for example, is ten times lower for zirconia than for alumina (Table 1). Cycle time and sintering power consumption depend on the thermal conductivity of the material [126]. The sintering cycle is selected in such a way as to ensure minimal grain growth of the sintered billets, which should provide higher physical and mechanical properties. 


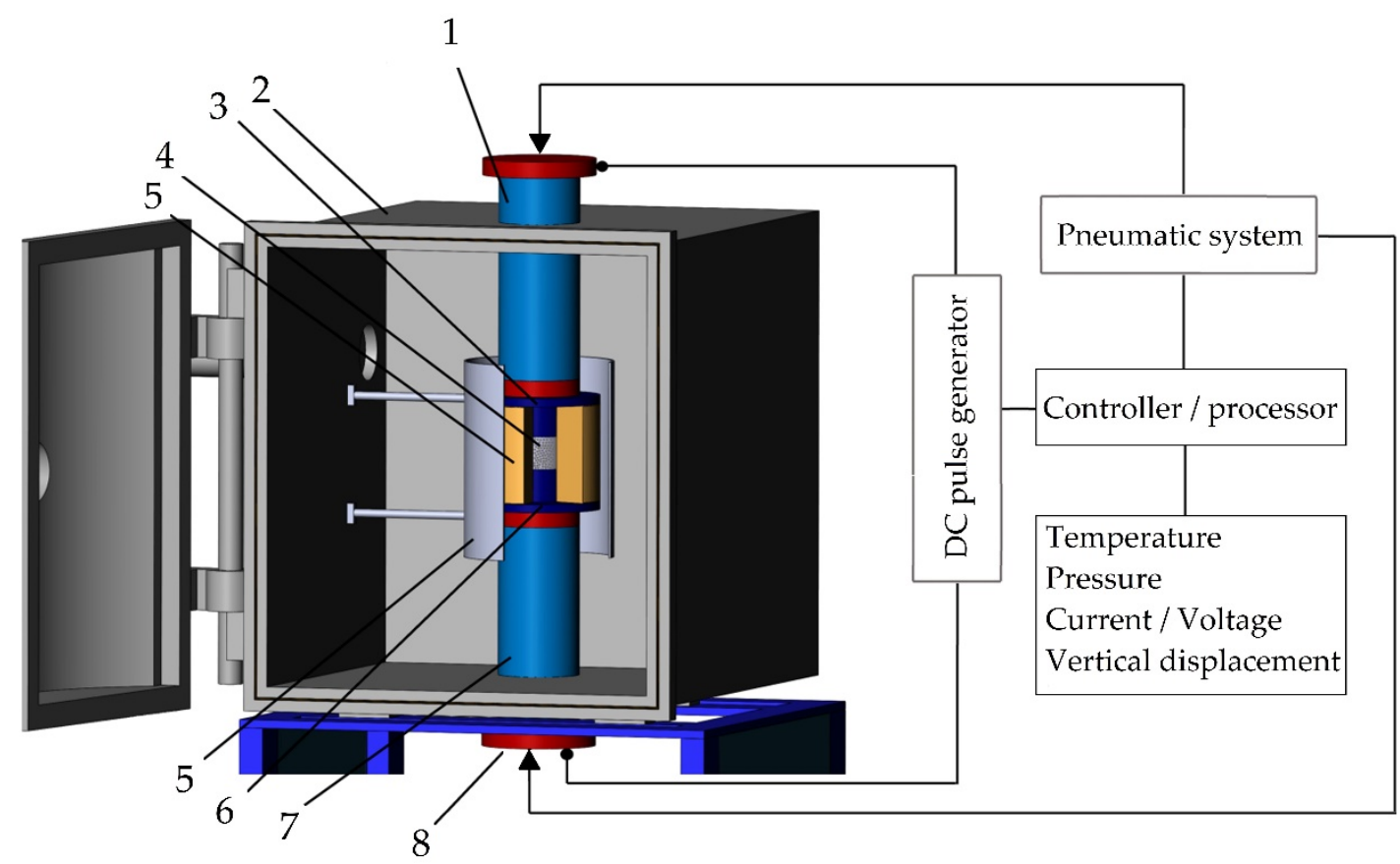

Figure 6. The configuration of the spark plasma sintering system developed in MSTU STANKIN: (1) is an upper electrode, (2) is a vacuum chamber, (3) is an upper punch, (4) is pressed powder, (5) is a die block, (6) is a heater, (7) is a lower punch, (8) is a lower electrode.

Conventional electric hot press processes using direct current or power are controlled by the basic process parameters that provide Joule sintering. These parameters or factors are related to the characteristics of the power supply, or high-frequency induction of the elements in combination with the smooth loading compacted powder materials through hydraulic or mechanical pressure.

The phenomena generated by spark plasma and pressure exclude the influence of gas adsorption, the formation of oxide films, and interactions with impurities and suspended particles that remain on the surface of the powder when a high-temperature field occurs. The action of the electromagnetic field is enhanced, and a high diffusion rate is provided by the rapid migration of ions. The local high-temperature state caused by impulse voltage is accompanied by vapors, solidification, and recrystallization.

SPS at high pressures is another version of the well-established method of spark sintering for shaping certain materials, such as superhard polycrystalline diamonds, cubic boron nitride, ceramic composites, nanocomposites, including those having refractory properties. Ceramics can also be synthesized into metastable phases or intermetallic alloys using the entire variety of SPS methods [127,128].

Since the sintering process is accompanied by uniaxial compression, the applied force is always limited by the high-temperature tensile strength of a graphite press tool, which is around 100-150 MPa. High pressure prevents the growth of grains in billets. It should be noted that there is a dependence between the physical properties of the sintered workpiece and the particle size of the ceramic powder, which is also determined by the different dispersion of the composition of the powder [129]. 
SPS consists of the following stages (Figure 7). In essence, vacuum conditions are created inside the working chamber, the workpiece is warmed up and is subjected to pressure, while at the point of contact of the powder particles there arises a spark discharge with the formed zones of local overheating, with continued heating, the surface of the powder grains reaches melting points, isthmuses form between particles, the mold is cooled down together with the workpiece.

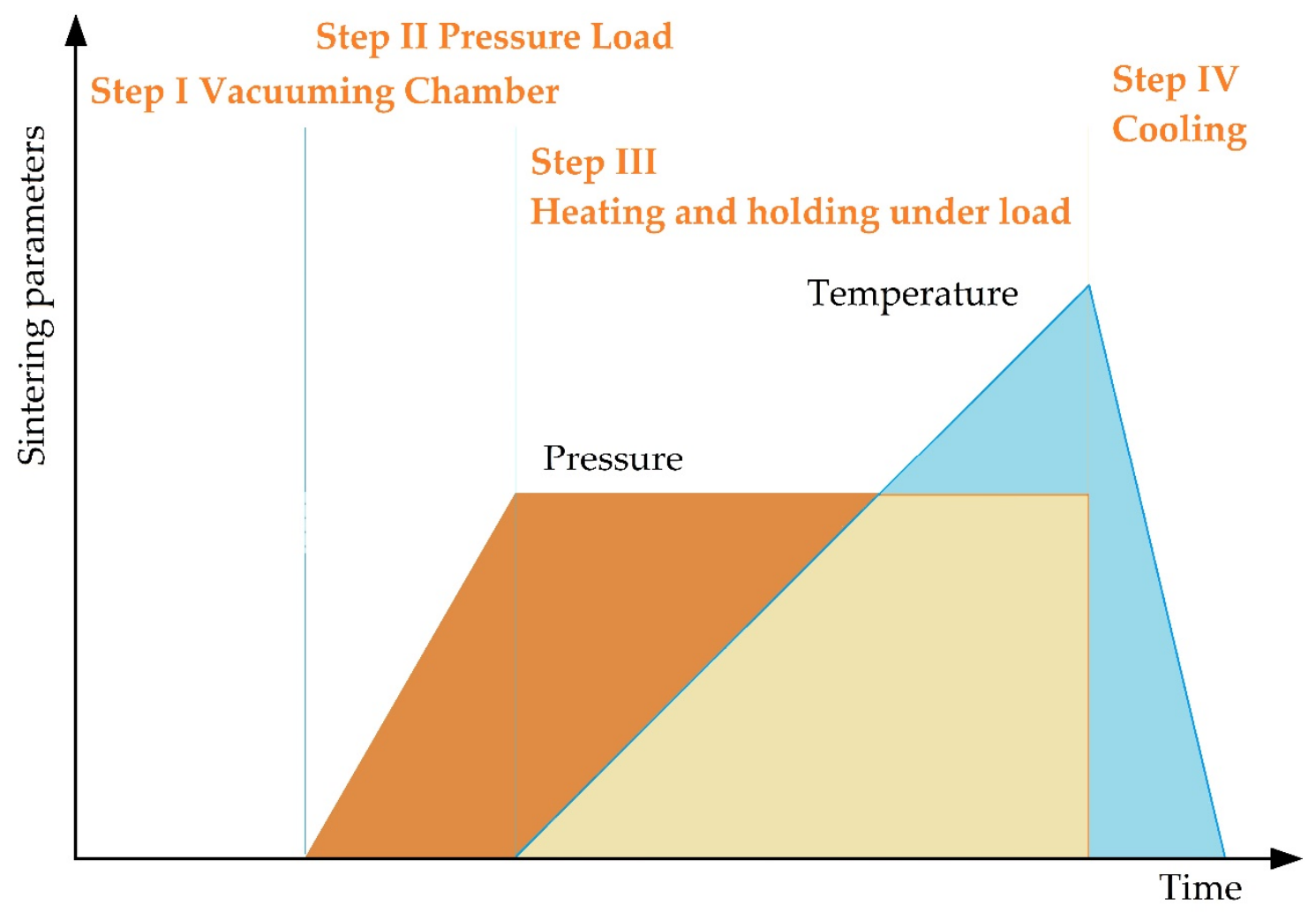

Figure 7. The main stages of spark plasma sintering.

The mold is heated using a sufficiently low voltage of $\sim 10 \mathrm{~V}$ and a current of up to $10 \mathrm{kA}$. The maximum achievable temperature in graphite molds is $2400^{\circ} \mathrm{C}$. The cooling rate reaches $150{ }^{\circ} \mathrm{C} / \mathrm{min}$ but can be increased to $400{ }^{\circ} \mathrm{C} / \mathrm{min}$ using additional gas cooling.

The sintering temperature is usually controlled either inside the wall of the graphite dies using a thermocouple, or superficially using a pyrometer during sintering. It should be noted that there are always differences in temperatures between the measured value and the actual sintering temperature in the mold. It has been experimentally established that the measured temperature during sintering metals and ceramic composites can vary between $50-250{ }^{\circ} \mathrm{C}$ in comparison with the actually achievable temperature in the center of the mold. The temperature measured on the surface is always lower than the actual value in the center of the preform.

The heterogeneity of heating can lead to increased porosity of the samples, which reduces not only physical and mechanical properties but also thermal and electrical conductivity of the final product $[4,5,38,126]$. The nature of electrical phenomena during sintering depends on the electrical properties of the raw material. 


\section{Chemical Interaction of Ceramics Components with Electrodes, Powders, and Medium}

Many materials change their electrical conductivity when heated and become semiconductors and conductors from insulators. A reverse transition is also possible for metals. Such properties during the design of the technology can have a positive effect on the electroerosive machinability of a part whose structure contains dielectric components that changes its conductivity in the presence of heat when the material surface forming the interelectrode gap reaches sublimation temperatures in the conditions of low-temperature plasma when forming the discharge channel to the auxiliary electrode.

The introduction of a powder or nanosized powder of titanium dioxide $\mathrm{TiO}_{2}$, cerium dioxide $\mathrm{CeO}_{2}$, and other ceramic components into the interelectrode gap is one of the most spread approaches in electrical discharge machining of ceramics $[4,24,25]$. When the discharge channel temperatures reach a certain level to provoke sublimation of the surface to be machined, some of the ceramics acquire conductive properties as it was mentioned above. That causes denser discharges of pulses in the interelectrode gap during processing the main conductive material, leading to higher performance and improved quality of the processed surfaces

Thus, the erosion products and the surface layer of the processed surfaces are formed directly from the components of ceramics, dielectric medium, auxiliary electrode, assisting powder, secondary phase of materials in the case of nanocomposites in the presence of heat, some of the possible chemical interactions for alumina $\mathrm{Al}_{2} \mathrm{O}_{3}$ and zirconia $\mathrm{ZrO}_{2}$ are provided in Table 2. It is necessary to carefully analyze the composition of all used primary and auxiliary materials before designing the processing conditions [130-137].

Table 2. The analytical chemical composition of erosion products and the subsurface layer of the processing surfaces during electrical erosion of some ceramics using a brass or copper electrode tool.

\begin{tabular}{|c|c|c|}
\hline $\begin{array}{l}\text { Auxiliary } \\
\text { Electrode }\end{array}$ & $\begin{array}{l}\text { Dielectric } \\
\text { Medium }\end{array}$ & Chemical Properties in the Presence of Heat \\
\hline & & $\mathrm{Al}_{2} \mathrm{O}_{3}$ ceramics $[19-22,138-143]$ \\
\hline \multirow[b]{2}{*}{ Any } & Water & $\begin{array}{l}\text { It is stable up to } 2044{ }^{\circ} \mathrm{C} \text {, chemically stable, insoluble in water, at } \\
1000{ }^{\circ} \mathrm{C} \text { it can interact with alkali metals to form aluminates as } \\
\mathrm{NaAlO}_{2} \text {, which react with water: } \\
\mathrm{NaAlO}_{2}+2 \mathrm{H}_{2} \mathrm{O} \rightarrow \mathrm{NaOH}+\mathrm{Al}(\mathrm{OH})_{3} \\
\text { During fusion, it can form anhydrous aluminates, for example, } \\
\mathrm{Ca}\left(\mathrm{AlO}_{2}\right)_{2} \text {, which with water can form calcium hydroaluminates, } \\
\mathrm{CaO} \cdot \mathrm{Al}_{2} \mathrm{O}_{3} \cdot \mathrm{H}_{2} \mathrm{O} \text { therefore it can only be processed in distilled and } \\
\text { deionized water }\end{array}$ \\
\hline & Oil/Kerosene & $\begin{array}{l}\text { Aluminum carbide } \mathrm{Al}_{4} \mathrm{C}_{3} \text { is obtained by direct reaction: } \\
4 \mathrm{Al}+3 \mathrm{C} \rightarrow \mathrm{Al}_{4} \mathrm{C}_{3} \\
\text { Or in the reaction of alumina } \mathrm{Al}_{2} \mathrm{O}_{3} \text { with carbon } \mathrm{C} \text { in the presence of } \\
\text { heating to } 1800{ }^{\circ} \mathrm{C} \text { : } \\
2 \mathrm{Al}_{2} \mathrm{O}_{3}+9 \mathrm{C} \rightarrow \mathrm{Al}_{4} \mathrm{C}_{3}+6 \mathrm{CO} \uparrow \\
\text { It is steady up to } 1400{ }^{\circ} \mathrm{C} \text {, reacts with water: } \\
\mathrm{Al}_{4} \mathrm{C}_{3}+12 \mathrm{H}_{2} \mathrm{O} \rightarrow 4 \mathrm{Al}(\mathrm{OH})_{3} \downarrow+3 \mathrm{CH}_{4} \uparrow \\
\text { With hydrogen at } 2200{ }^{\circ} \mathrm{C} \text { : } \\
\mathrm{Al}_{4} \mathrm{C}_{3}+6 \mathrm{H}_{2} \uparrow \rightarrow 4 \mathrm{Al}+3 \mathrm{CH} \mathrm{H}_{4} \uparrow \\
\text { With oxygen at } 650-700{ }^{\circ} \mathrm{C}: \\
\mathrm{Al}_{4} \mathrm{C}_{3}+6 \mathrm{O}_{2} \uparrow \rightarrow 2 \mathrm{Al}_{2} \mathrm{O}_{3}+3 \mathrm{CO}_{2} \uparrow \\
\text { It is used in pyrotechnics }\end{array}$ \\
\hline
\end{tabular}


Table 2. Cont.

\begin{tabular}{|c|c|c|}
\hline $\begin{array}{l}\text { Auxiliary } \\
\text { Electrode }\end{array}$ & $\begin{array}{l}\text { Dielectric } \\
\text { Medium }\end{array}$ & Chemical Properties in the Presence of Heat \\
\hline \multirow{4}{*}{$\mathrm{Ti}, \mathrm{Cr}, \mathrm{Co}, \mathrm{C}$} & \multirow{4}{*}{ Water } & $\begin{array}{l}\text { Titanium(IV) dioxide } \mathrm{TiO}_{2} \text { becomes a semiconductor at } 1000^{\circ} \mathrm{C} \\
\text { with specific electrical conductivity up to } 10^{3} \mathrm{~S} \cdot \mathrm{m}^{-1}\end{array}$ \\
\hline & & 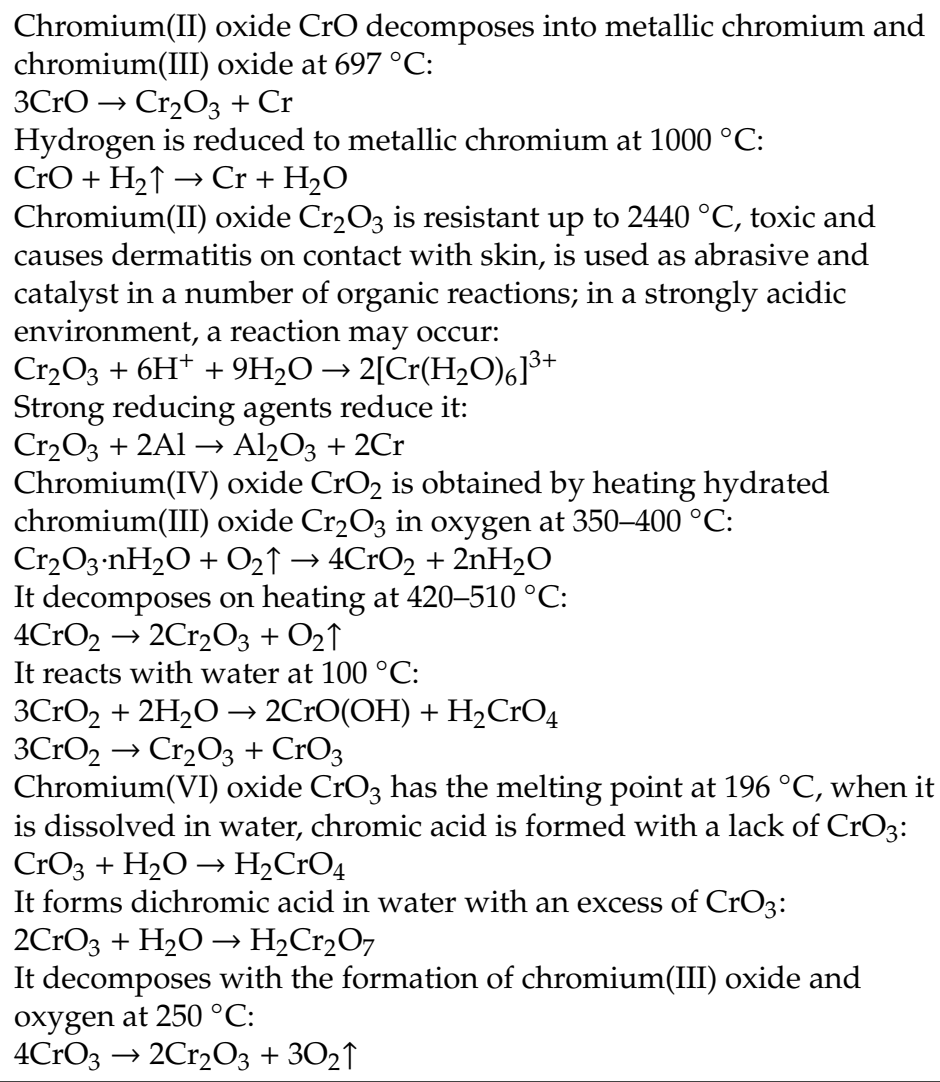 \\
\hline & & $\begin{array}{l}\text { Cobalt oxide } \mathrm{Co}_{3} \mathrm{O}_{4} \text { is a complex oxide having a spinel structure } \\
\text { and stable at room temperature; it decomposes with the formation } \\
\text { of cobalt monoxide } \mathrm{CoO} \text { at temperatures above } 900{ }^{\circ} \mathrm{C} \\
\text { The } \alpha \text {-form or } \beta \text {-form of cobalt monoxide } \mathrm{CoO} \text { can be obtained at } \\
\text { high temperatures } \\
\text { All cobalt oxide } \mathrm{Co}_{3} \mathrm{O}_{4} \text { is reduced with hydrogen: } \\
\mathrm{Co}_{3} \mathrm{O}_{4}+4 \mathrm{H}_{2} \uparrow \rightarrow 3 \mathrm{Co}+4 \mathrm{H}_{2} \mathrm{O}\end{array}$ \\
\hline & & Aluminum carbide $\mathrm{Al}_{4} \mathrm{C}_{3}$ can be formed \\
\hline \multirow{4}{*}{$\mathrm{Zn}, \mathrm{Ag}, \mathrm{Au}, \mathrm{Al}$} & \multirow{4}{*}{ Water } & $\begin{array}{l}\text { Zinc oxide } \mathrm{ZnO} \text { sublimates at a temperature of } 1800^{\circ} \mathrm{C} \text {, when fused } \\
\text { with silicon dioxide forms a refractory glassy silicate } \mathrm{ZnSiO}_{3}\end{array}$ \\
\hline & & $\begin{array}{l}\text { Silver(I) oxide } \mathrm{Ag}_{2} \mathrm{O} \text { decomposes when heated above } 280{ }^{\circ} \mathrm{C} \\
\text { Silver(I,III) oxide } \mathrm{Ag}_{2} \mathrm{O}_{2} \text { decomposes when heated above } 100{ }^{\circ} \mathrm{C}\end{array}$ \\
\hline & & $\begin{array}{l}\text { Gold(I) oxide } \mathrm{Au}_{2} \mathrm{O} \text { is unstable under normal conditions, } \\
\text { decomposes in } \mathrm{Au} \text { and } \mathrm{Au}_{2} \mathrm{O}_{3} \text { at } 225^{\circ} \mathrm{C} \\
\text { Gold(II) oxide } \mathrm{Au}_{2} \mathrm{O}_{3} \text { is stable, has excellent conductive properties, } \\
\text { is used in microelectronics }\end{array}$ \\
\hline & & $\begin{array}{l}\text { Alumina } \mathrm{Al}_{2} \mathrm{O}_{3} \text { is insoluble in water, is an n-type dielectric or } \\
\text { semiconductor at nominal pressure }\end{array}$ \\
\hline
\end{tabular}


Table 2. Cont.

\begin{tabular}{|c|c|c|}
\hline $\begin{array}{l}\text { Auxiliary } \\
\text { Electrode }\end{array}$ & $\begin{array}{l}\text { Dielectric } \\
\text { Medium }\end{array}$ & Chemical Properties in the Presence of Heat \\
\hline & & $\mathrm{ZrO}_{2}$ ceramics $[144-150]$ \\
\hline \multirow{4}{*}{ Any } & \multirow{3}{*}{ Any } & Becomes a semiconductor in the presence of temperatures \\
\hline & & $\begin{array}{l}\text { The released zirconium has the property to burn in oxygen at a } \\
\text { self-ignition temperature of } 250{ }^{\circ} \mathrm{C} \text { with high speed and smokeless, } \\
\text { which is why it has become widespread in pyrotechnics }\end{array}$ \\
\hline & & $\begin{array}{l}\text { The released zirconium actively absorbs hydrogen forming } \\
\text { hydrides } \mathrm{ZrH}_{\mathrm{x}} \text { at } 250-300{ }^{\circ} \mathrm{C}[151] \text { that can develop } \\
\text { super-conducting properties under pressure of } 150 \mathrm{GPa} \text { at } \\
10.6 \mathrm{~K} \text { [152]; the hydrides dissociate at } 1200-1300{ }^{\circ} \mathrm{C}\end{array}$ \\
\hline & \multirow{5}{*}{ Water } & Does not interact with water \\
\hline \multirow{3}{*}{$\mathrm{Ti}, \mathrm{Cr}, \mathrm{Co}, \mathrm{C}$} & & $\begin{array}{l}\text { Most of the possible components' interactions are similar to the } \\
\text { mentioned above }\end{array}$ \\
\hline & & $\begin{array}{l}\text { The sublimation point of carbon } \mathrm{C} \text { is } 3642{ }^{\circ} \mathrm{C} \text {; it does not exist in } \\
\text { liquid form at normal pressures }\end{array}$ \\
\hline & & $\begin{array}{l}\text { Zirconium forms zirconium carbide } \mathrm{ZrC} \text { with carbon } \mathrm{C} \text {, which is an } \\
\text { excellent conductor, at temperatures above } 900{ }^{\circ} \mathrm{C} \text {; its electrical } \\
\text { properties are similar to those of pure zirconium }\end{array}$ \\
\hline $\mathrm{Zn}, \mathrm{Ag}, \mathrm{Au}, \mathrm{Al}$ & & $\begin{array}{l}\text { Most of the components' interactions are similar to the } \\
\text { mentioned above }\end{array}$ \\
\hline Any & \multirow{8}{*}{ Oil/Kerosene } & It forms zirconium carbide $\mathrm{ZrC}$ at temperatures above $900^{\circ} \mathrm{C}$ \\
\hline \multirow{4}{*}{$\mathrm{Ti}, \mathrm{Cr}, \mathrm{Co}, \mathrm{C}$} & & $\begin{array}{l}\text { The formed titanium carbide } \mathrm{TiC} \text { has a slightly higher electrical } \\
\text { resistance than titanium nitride, a semiconductor, becomes a } \\
\text { conductor with increasing temperature }\end{array}$ \\
\hline & & $\begin{array}{l}\text { Chromium carbide } \mathrm{Cr}_{3} \mathrm{C}_{2} \text { has the specific electrical conductivity }{ }^{*} \text { of } \\
1.3 \times 10^{6} \mathrm{~S} \cdot \mathrm{m}^{-1} ; \text { chromium carbides have melting point in the range } \\
\text { of } 1520-1890{ }^{\circ} \mathrm{C} \text {; chromium carbide } \mathrm{Cr}_{7} \mathrm{C}_{3} \text { turns into } \mathrm{Cr}_{23} \mathrm{C}_{6} \text { after } \\
\text { prolonged heating at } 730-870{ }^{\circ} \mathrm{C} ; \mathrm{Cr}_{3} \mathrm{C}_{2} \text { carbide insoluble in water } \\
\text { but it can interact with zinc } \mathrm{Zn} \text { at a temperature of } 940{ }^{\circ} \mathrm{C} \text {; the } \\
\text { oxidation of chromium carbide begins at temperatures of } \\
700-1100{ }^{\circ} \mathrm{C}\end{array}$ \\
\hline & & $\begin{array}{l}\text { Tricobalt carbide } \mathrm{Co}_{3} \mathrm{C} \text { in the presence of } 3 \mathrm{Co}+\mathrm{C} \text { at a temperature } \\
\text { of } 1800{ }^{\circ} \mathrm{C} \text { decomposes upon crystallization. At temperatures above } \\
230{ }^{\circ} \mathrm{C} \text {, tricobalt carbide reacts with hydrogen to form methane at } \\
250{ }^{\circ} \mathrm{C} \text {, while methane and metallic cobalt are released }\end{array}$ \\
\hline & & $\begin{array}{l}\text { Copper(I) acetylenide } \mathrm{Cu}_{2} \mathrm{C}_{2} \text { in dry form is explosive, detonates } \\
\text { when heated or impact, forms hydrates in the presence of water } \\
\mathrm{Cu}_{2} \mathrm{C}_{2} \cdot \mathrm{H}_{2} \mathrm{O} \\
\text { Copper(II) acetylenide } \mathrm{CuC}_{2} \text { forms hydrates in the presence of } \\
\text { water } \mathrm{CuC} \cdot \frac{1}{2} \mathrm{H}_{2} \mathrm{O} \text {, insoluble in water, but decomposes with } \\
\text { explosion upon drying and loss of water }\end{array}$ \\
\hline \multirow{3}{*}{$\mathrm{Zn}, \mathrm{Ag}, \mathrm{Au}, \mathrm{Al}$} & & $\begin{array}{l}\text { Zinc carbide } \mathrm{ZnC}_{2} \text { reacts with water to form acetylene (colorless } \\
\text { flammable gas): } \\
\mathrm{ZnC}_{2}+2 \mathrm{H}_{2} \mathrm{O} \rightarrow \mathrm{Zn}(\mathrm{OH})_{2}+\mathrm{C}_{2} \mathrm{H}_{2} \uparrow\end{array}$ \\
\hline & & $\begin{array}{l}\text { Silver acetylide } \mathrm{Ag}_{2} \mathrm{C}_{2}(\mathrm{CAg} \equiv \mathrm{CAg}) \text { is a very unstable and explosive } \\
\text { compound, explodes when heated and mechanically exposed }\end{array}$ \\
\hline & & $\begin{array}{l}\text { Gold carbide } \mathrm{Au}_{2} \mathrm{C}_{2} \text { is insoluble in water and explosive, with } \\
\text { ammonia forms an explosive adduct } \mathrm{Au}_{2} \mathrm{C}_{2} \cdot \mathrm{NH}_{3}\end{array}$ \\
\hline
\end{tabular}


As can be seen in Table 2, titanium Ti and chromium $\mathrm{Cr}$ are most suited for electrical discharge machining of zirconia $\mathrm{ZrO}_{2}$ in oil or kerosene from all considered transition metals as they provoke the formation of conductive particles in the interelectrode gap.

EDM of zirconia $\mathrm{ZrO}_{2}$ in oil or kerosene and with assisting carbon particles or nanotubes can form conductive zirconium carbide $\mathrm{ZrC}$ by interacting with oil or kerosene decomposition components and elements of the auxiliary electrode or assisting powder. Then the erosion products can contribute to a denser erosion in the interelectrode gap.

Zirconia $\mathrm{ZrO}_{2}$ tends to change its electrical properties in the presence of heat up to $2000{ }^{\circ} \mathrm{C}$ (Figure 3), but it is inert to the water medium. The zirconium starts actively to absorb hydrogen $\mathrm{H}_{2}$ at temperatures around $250-300{ }^{\circ} \mathrm{C}$ forming solid solution and hydrides $\mathrm{ZrH}_{\mathrm{x}}(\mathrm{x}=0.05-2)$ representing fragile sulfur black powder. The hydride powder is stable at room temperature but ignites at $430^{\circ} \mathrm{C}$ on the air when the hydride crystals are stable up to $600-750{ }^{\circ} \mathrm{C}$ and then they decompose with the release of hydrogen and dissociate to the pure metal at $1200-1300^{\circ} \mathrm{C}$ in a vacuum $[153,154]$. Thus, the released hydrides may not cause any difficulties during electrical discharge machining.

Processing alumina $\mathrm{Al}_{2} \mathrm{O}_{3}$ in water should not provoke the appearance of new chemically active substances in the interelectrode gap, while processing in oil or kerosene can cause of damage of the filtration system of the equipment due to the formation of explosive and chemically active aluminum carbide $\mathrm{Al}_{4} \mathrm{C}_{3}$.

It seems that the use of copper $\mathrm{Cu}$, silver $\mathrm{Ag}$, gold $\mathrm{Au}$, or aluminum $\mathrm{Al}$ in the form of the film is the most suitable for $\mathrm{EDM}$ of alumina $\mathrm{Al}_{2} \mathrm{O}_{3}$ in water. In normal conditions, alumina of the workpiece, an oxide film of the auxiliary electrode made of aluminum, and formed alumina particles in the process of electrical erosion are inert to water. $\mathrm{Ag}$ and $\mathrm{Au}$ films and their oxide films do not form compounds that are resistant to high temperatures: the formed gold(III) oxide $\mathrm{Au}_{2} \mathrm{O}_{3}$ is a thermally unstable conductor.

It should be noted that, usually, EDM in oil or kerosene provides more uniform morphology than in water due to more even heat removal from the treatment zone and the damping effect of a more viscous medium to compensate for forced oscillations of the wire electrode during processing $[4,11,26,49]$.

The use of cerium(IV) dioxide $\mathrm{CeO}_{2}$ (Table 3) as an assisting powder with brass wire or profiled electrode is not highly recommended. It has a similar but brighter nature as the uses of the brass tool during EDM of nickel-containing steel or Ni-coated workpieces. The cerium Ce and nickel Ni react with zinc $\mathrm{Zn}$ of brass very actively with the formation of intermetallides. The reaction of nickel $\mathrm{Ni}$ and zinc $\mathrm{Zn}$ at temperatures above $1000^{\circ} \mathrm{C}$ has an explosive character that can be observed as a series of sparks in the interelectrode gap during processing $[26,44,53,155,156]$. The reaction of cerium Ce and zinc $\mathrm{Zn}$ has a more violent character that is typical for cerium. The reaction at high temperatures during local heating and consequent fusion of two powders provide a bright flash and a powerful explosion [157,158].

One of the useful properties of titanium carbide TiC assisting powder can be its interaction with nitrogen $\mathrm{N}$ at a temperature above $2500^{\circ} \mathrm{C}$. It forms conductive titanium nitride TiN that can be an advantage in EDM of non-conductive silicon nitride $\mathrm{Si}_{3} \mathrm{~N}_{4}[27,28]$. 
Table 3. The analytical chemical composition of erosion products and the subsurface layer of the processing surface during electrical erosion of some ceramics using a brass or copper electrode tool [129,159-163].

\begin{tabular}{|c|c|c|}
\hline $\begin{array}{l}\text { Assisting } \\
\text { Powder }\end{array}$ & $\begin{array}{l}\text { Dielectric } \\
\text { Medium }\end{array}$ & Chemical Properties in the Presence of Heat \\
\hline \multicolumn{3}{|r|}{$\mathrm{Al}_{2} \mathrm{O}_{3}$ ceramics } \\
\hline \multicolumn{3}{|r|}{+ conductive additives } \\
\hline W & & $\begin{array}{l}\text { Tungsten } \mathrm{W} \text { is heat- and chemically resistant under standard conditions; } \\
\text { the sublimation point is } 3422{ }^{\circ} \mathrm{C} \text {; it exists in liquid form only at high } \\
\text { pressures; it is slowly oxidized to tungsten(VI) trioxide } \mathrm{WO}_{3} \text { at a } \\
\text { temperature of red heat; oxidation of tungsten } \mathrm{W} \text { in an atmosphere of } \\
\text { oxygen occurs at temperatures above } 500{ }^{\circ} \mathrm{C} \text { : } \\
2 \mathrm{~W}+3 \mathrm{O}_{2} \uparrow \rightarrow 2 \mathrm{WO}_{3} \\
\text { It is reduced to metallic tungsten } \mathrm{W} \text { by hydrogen at a temperature of } \\
700-900^{\circ} \mathrm{C}\end{array}$ \\
\hline $\mathrm{Cu}$ & Water & $\begin{array}{l}\text { Melting point is } 1083.4{ }^{\circ} \mathrm{C} \text {, it is oxidized to copper(I) oxide } \mathrm{Cu}_{2} \mathrm{O} \text {, which } \\
\text { does not react with water and dissociates to a small degree, with oxygen } \\
\text { deficiency at a temperature of } 200{ }^{\circ} \mathrm{C} \text { : } \\
4 \mathrm{Cu}+\mathrm{O}_{2} \uparrow \rightarrow 2 \mathrm{Cu} \mathrm{O} \\
\text { and to copper(II) oxide } \mathrm{CuO} \text { with oxygen excess at temperatures of about } \\
400-500{ }^{\circ} \mathrm{C} \text { or by heating metallic copper in the air at temperatures below } \\
1100{ }^{\circ} \mathrm{C}: \\
2 \mathrm{Cu}+\mathrm{O}_{2} \uparrow \rightarrow 2 \mathrm{CuO} \\
\mathrm{Copper}(\mathrm{II}) \text { oxide } \mathrm{CuO} \text { is reduced to metallic copper by hydrogen } \\
\text { (exothermic reaction): } \\
\mathrm{CuO}+\mathrm{H}_{2} \uparrow \rightarrow \mathrm{Cu}+\mathrm{H}_{2} \mathrm{O}+\mathrm{Q} \uparrow \\
\mathrm{It} \text { also decomposes into copper } \mathrm{Cu} \text { and oxygen } \mathrm{O} \text {, when heated to } 1100{ }^{\circ} \mathrm{C}\end{array}$ \\
\hline \multicolumn{3}{|r|}{+ oxide ceramics } \\
\hline $\mathrm{TiO}_{2}$ & \multirow{4}{*}{ Water } & $\begin{array}{l}\text { As was mentioned above, titanium(IV) dioxide } \mathrm{TiO}_{2} \text { becomes a } \\
\text { semiconductor at } 1000^{\circ} \mathrm{C} \text { with electrical conductivity up to } 10^{3} \mathrm{~S} \cdot \mathrm{m}^{-1}\end{array}$ \\
\hline $\mathrm{CeO}_{2}$ & & $\begin{array}{l}\text { Cerium(IV) dioxide } \mathrm{CeO}_{2} \text { has a relatively high ionic conductivity of oxygen } \\
\text { at } 500-800^{\circ} \mathrm{C} \text {; it also exhibits high electronic conductivity at low oxygen } \\
\text { partial pressures; melting point is } 2400{ }^{\circ} \mathrm{C} \text {; refectory material up to } 2300{ }^{\circ} \mathrm{C} \\
\text { in an oxidizing or inert atmosphere; cerium(IV) oxide reduces to cerium(III) } \\
\text { oxide } \mathrm{Ce}_{2} \mathrm{O}_{3} \text { with hydrogen gas at about } 1400{ }^{\circ} \mathrm{C} \text { : } \\
2 \mathrm{CeO}_{2}+\mathrm{H}_{2} \uparrow \rightarrow \mathrm{Ce}_{2} \mathrm{O}_{3}+\mathrm{H}_{2} \mathrm{O} \\
\text { And, on the contrary, cerium(III) oxide is oxidized to cerium(IV) oxide with } \\
\text { an excess of oxygen: } \\
2 \mathrm{Ce}_{2} \mathrm{O}_{3}+\mathrm{O}_{2} \uparrow \rightarrow 4 \mathrm{CeO}_{2} \\
\text { Cerium(III) oxide } \mathrm{Ce}_{2} \mathrm{O}_{3} \text { is stable on air, but cerium Ce in powder is } \\
\text { pyrophoric and unstable at room temperature; presence cerium as an } \\
\text { alloying element for aluminum alloy reduces its conductivity; the melting } \\
\text { point is } 217{ }^{\circ} \mathrm{C} \\
\text { Cerium Ce reacts fulminant with some metals as zinc Zn at higher } \\
\text { temperatures and forms intermetallides with heat and light emission; thus } \\
\text { using a brass tool is not recommended for EDM in the presence of } \\
\text { cerium Ce }\end{array}$ \\
\hline $\mathrm{SnO}_{2}$ & & $\begin{array}{l}\text { Tin(IV) oxide is a wide-gap n-type semiconductor, electrical resistivity } 3.4 \times \\
10^{3} \Omega \cdot \mathrm{cm} \text { (electrical conductivity } \sim 2.94 \times 10^{2} \mathrm{~S} \cdot \mathrm{m}^{-1} \text { ); doping with elements } \\
\text { of group V (for example, antimony Sb) increases electrical conductivity by } \\
\text { three-five orders of magnitude; the melting point is } 1630^{\circ} \mathrm{C} \text {; it evaporates } \\
\text { with the decomposition of tin monoxide } \mathrm{SnO} \text { (and its di-, tri- and tetramers) } \\
\text { and oxygen at high temperatures; it is restored by hydrogen to metal tin at } \\
500-600{ }^{\circ} \mathrm{C} \text { : } \\
\mathrm{SnO}_{2}+2 \mathrm{H}_{2} \uparrow \rightarrow \mathrm{Sn}+2 \mathrm{H}_{2} \mathrm{O}\end{array}$ \\
\hline ITO & & $\begin{array}{l}\text { Indium tin oxide (ITO) is semiconductor material with n-type conductivity } \\
\text { comparable to metallic, where tin ions serve as electron donors; it is a solid } \\
\text { solution of } 90 \% \text { indium(III) oxides and } 10 \% \text { tin(IV) }\left(\mathrm{In}_{2} \mathrm{O}_{3}\right)_{0.9}-\left(\mathrm{SnO}_{2}\right)_{0.1} ; \\
\text { insoluble in water and extremely expensive in applications due to } \\
\text { its transparency }\end{array}$ \\
\hline
\end{tabular}


Table 3. Cont.

\begin{tabular}{|c|c|c|}
\hline $\begin{array}{l}\text { Assisting } \\
\text { Powder }\end{array}$ & $\begin{array}{l}\text { Dielectric } \\
\text { Medium }\end{array}$ & Chemical Properties in the Presence of Heat \\
\hline & & $\mathrm{ZrO}_{2}$ ceramics \\
\hline & & + conductive additives \\
\hline \multirow[t]{2}{*}{ WC } & Any & $\begin{array}{l}\text { The specific electrical conductivity } * \text { is } \sim 5.22 \times 10^{2} \mathrm{~S} \cdot \mathrm{m}^{-1} \text {; significant and } \\
\text { rapid oxidation of tungsten carbide } \mathrm{WC} \text { in air begins at } 500-700^{\circ} \mathrm{C} \text {, and it is } \\
\text { completely oxidized due to the high volatility of tungsten oxide at } \\
\text { temperatures above } 800{ }^{\circ} \mathrm{C} \text { : } \\
\mathrm{WC}+2 \mathrm{O}_{2} \rightarrow \mathrm{WO}_{3}+\mathrm{CO} \uparrow \\
\text { Tungsten(VI) trioxide } \mathrm{WO}_{3} \text { is reduced as well to metallic tungsten } \mathrm{W} \text { by } \\
\text { hydrogen } \mathrm{H} \text { as it was mentioned above } \\
\text { The temperature stability range for } \mathrm{W}_{2} \mathrm{C} \text { is up to } 2750{ }^{\circ} \mathrm{C} \text {; it is up to } 2600{ }^{\circ} \mathrm{C} \\
\text { for } \mathrm{WC} ; \mathrm{WC} \text { weakly interacts with a zinc melt at a temperature of } 940{ }^{\circ} \mathrm{C}\end{array}$ \\
\hline & Oil/Kerosene & $\begin{array}{l}\text { Tungsten(VI) trioxide } \mathrm{WO}_{3} \text { is reduced as well to metallic tungsten } \mathrm{W} \text { by } \\
\text { carbon } \mathrm{C} \text { at a temperature of } 1000^{\circ} \mathrm{C}\end{array}$ \\
\hline \multirow[t]{2}{*}{$\mathrm{TiC}$} & Any & $\begin{array}{l}\text { Melting point is } \sim 3260^{\circ} \mathrm{C} \text {; it begins to react with nitrogen } \mathrm{N} \text { at high } \\
\text { temperatures above } 2500{ }^{\circ} \mathrm{C} \text {; it is decarburized during interacting with } \\
\text { hydrogen } \mathrm{H} \text {; the temperature of the active oxidation of titanium carbide is } \\
1100-1200{ }^{\circ} \mathrm{C} \text {; the temperature stability range of titanium carbide TiC is } \\
\text { below } 3140{ }^{\circ} \mathrm{C} \text {; it is highly resistant to molten low-melting metals and } \\
\text { metals such as copper, aluminum, brass, cast irons and steels }\end{array}$ \\
\hline & Oil/Kerosene & It is oxidized by carbon dioxide $\mathrm{CO}_{2}$ at temperatures above $1200^{\circ} \mathrm{C}$ \\
\hline $\mathrm{Cu}$ & Oil/Kerosene & $\begin{array}{l}\text { It should be noted to the mentioned above that copper(II) oxide } \mathrm{CuO} \text { is } \\
\text { reduced as well to copper } \mathrm{Cu} \text { by carbon(II) monoxide } \mathrm{CO} \text { and carbon } \mathrm{C} \text { : } \\
2 \mathrm{CuO}+\mathrm{C} \rightarrow 2 \mathrm{Cu}+\mathrm{CO}_{2} \uparrow\end{array}$ \\
\hline \multicolumn{3}{|r|}{ + oxide ceramics } \\
\hline $\mathrm{TiO}_{2}$ & \multirow{3}{*}{ Oil/Kerosene } & $\begin{array}{l}\text { As it was mentioned above, the formed titanium carbide TiC has a slightly } \\
\text { higher electrical resistance than titanium nitride TiN (less electrically } \\
\text { conductive); it is a semiconductor; it becomes a conductor with } \\
\text { increasing temperature }\end{array}$ \\
\hline $\mathrm{CeO}_{2}$ & & $\begin{array}{l}\text { Cerium(IV) oxide is reduced by carbon(II) monoxide } \mathrm{CO} \text { to cerium(III) } \\
\text { oxide, when there is not enough oxygen: } \\
4 \mathrm{CeO}_{2}+2 \mathrm{CO} \rightarrow 2 \mathrm{Ce}_{2} \mathrm{O}_{3}+2 \mathrm{CO}_{2} \uparrow \\
\text { The contrary reaction as presented in (27) }\end{array}$ \\
\hline $\mathrm{SnO}_{2}$ & & $\begin{array}{l}\text { It should be added to the mentioned above, it is restored as well by carbon } \\
\text { to metal tin at } 800-900^{\circ} \mathrm{C}: \\
\mathrm{SnO}_{2}+2 \mathrm{C} \rightarrow \mathrm{Sn}+2 \mathrm{CO} \uparrow\end{array}$ \\
\hline
\end{tabular}

\section{Conclusions}

It was shown that the erosion products and subsurface layer of the machined surfaces are formed directly from the components of ceramics, dielectric medium, auxiliary electrode, assisting powder during electrodes sublimation in the presence of heat. The chemical composition of the subsurface layer of the machined surfaces and the machinability of new materials not always depends on the electrophysical properties of the material but also on the combination of the materials of the primary and auxiliary electrode, conductive additives, assisting powder and workpiece.

All possible component interactions should be taken into account when developing the technology for electrical discharge machining non-conductive ceramics since the formation of certain chemicals in the form of insoluble or pyrotechnically dangerous sludge and gas can have dramatic consequences for the quality of the machined surfaces, the service life of the equipment and its units, and even for personnel.

The ceramic pressing methods, electrophysical and chemical properties of components in the presence of heat, data on possible interactions, and suitable combinations of the materials for processing 
structural oxide ceramics were presented for the most spread aluminum oxide and zirconium dioxide but can be applied for functional ceramics and nanocomposites.

According to the conducted analytical study, electrical discharge machining in oil or kerosene medium gives better qualities of the machined surface. A uniform surface morphology is formed due to more uniform heat removal and the damping effect of a more viscous medium to compensate for forced oscillations of the wire tool.

Titanium and chromium are most suited from the considered transition metals, taking into account the basic principles of physical chemistry, the laws of the structures of substances, their structure and transformations, available theoretical and practical data for electric discharge machining in oil or kerosene. They allow obtaining electrically conductive substances as erosion products, which can contribute to more dense erosion in the interelectrode gap.

During processing in a water medium, the use of silver, gold, aluminum as an auxiliary electrode are more suitable for copper or brass electrode, since aluminum is inert to water, silver and gold do not form compounds that are resistant at high temperatures. Moreover, the formed $\mathrm{Au}_{2} \mathrm{O}_{3}$ is the conductor but not heat-resistant.

Machining alumina in water should not provoke the appearance of chemically active substances in the interelectrode gap, while processing in oil or kerosene can have a negative influence on the filtration system of the equipment due to the formation of explosive and chemically active $\mathrm{Al}_{4} \mathrm{C}_{3}$ in the treatment zone. It is also evident that sintering alumina cannot be implemented in carbon dies, as the consequences of this combination can be non-electrical nature of the workpiece destruction and rapid wear of die paddings.

Probably, applying the brass tool during machining nickel alloys should be revised to the direction of using more chemically neutral to nickel materials.

Cerium dioxide cannot be used as assisting powder in combination with a brass tool as well.

During the development of the technology for ceramic machining, the preferred materials for the auxiliary electrodes, assisting powder and conductive particles should be the materials that provide conductive erosion dust in the interelectrode gap.

The developed approaches in electrical discharge machining structural ceramics can have an impact on the industry if the obtained data will be taken into account.

Author Contributions: Conceptualization, M.A.V.; methodology, A.A.O.; software, M.A.M.; validation, K.H.; formal analysis, K.H.; investigation, S.V.F.; resources, S.V.F.; data curation, M.A.M.; writing-original draft preparation, K.H., M.A.M.; writing-review \& editing, A.A.O.; visualization, A.A.O.; supervision, S.V.F.; project administration, M.A.V.; funding acquisition, M.A.V. All authors have read and agreed to the published version of the manuscript.

Funding: This research was financially supported by the Russian Foundation for Basic Research, grant number 19-08-00899.

Acknowledgments: The research was done at the Department of High-Efficiency Processing Technologies of MSTU Stankin.

Conflicts of Interest: The authors declare no conflict of interest.

\section{References}

1. Grigoriev, S.N.; Gurin, V.D.; Volosova, M.A.; Cherkasova, N.Y. Development of residual cutting tool life prediction algorithm by processing on CNC machine tool. Mater. Werkst. 2013, 44, 790-796. [CrossRef]

2. Qudeiri, J.E.A.; Zaiout, A.; Mourad, A.-H.I.; Abidi, M.H.; Elkaseer, A. Principles and characteristics of different EDM processes in machining tool and die steels. Appl. Sci. 2020, 10, 2082. [CrossRef]

3. Mouangue Nanimina, A.; Abdul-Rani, A.M.; Ahmad, F.; Zainuddin, A.; Jason Lo, S.H. Effects of Electro-discharge Machining on Aluminium Metal Matrix Composite. J. Appl. Sci. 2011, 11, 1668-1672. [CrossRef]

4. Grigoriev, S.N.; Kozochkin, M.P.; Porvatov, A.N.; Volosova, M.A.; Okunkova, A.A. Electrical discharge machining of ceramic nanocomposites: Sublimation phenomena and adaptive control. Heliyon 2019, 5, e02629. [CrossRef] [PubMed] 
5. Grigoriev, S.N.; Melnik, Y.A.; Metel, A.S.; Panin, V.V. Broad beam source of fast atoms produced as a result of charge exchange collisions of ions accelerated between two plasmas. Instrum. Exp. Tech. 2009, 52, 602-608. [CrossRef]

6. Grigoriev, S.; Metel, A. Plasma and beam-assisted deposition methods. In Nanostructured Thin Films and Nanodispersion Strengthened Coatings; Voevodin, A.A., Shtansky, D.V., Levashov, E.A., Moore, J.J., Eds.; Kluwer Academic Publishers: New York, NY, USA; Boston, MA, USA; Dordrecht, The Netherlands; London, UK; Moscow, Russia, 2004; pp. 147-154.

7. Grigoriev, S.; Melnik, Y.; Metel, A. Broad fast neutral molecule beam sources for industrial-scale beam-assisted deposition. Surf. Coat. Tech. 2002, 156, 44-49. [CrossRef]

8. Wijaya, H.; Wahyudi, S.; Soenoko, R.; Setyarini, P.H.; Yasid, S.; Gapsari, F. The effect of power supply current on recast layer in S45C steel using wire EDM. IOP Conf. Ser. Mater. Sci. Eng. 2019, 494, 012102. [CrossRef]

9. Muthuramalingam, T. Measuring the influence of discharge energy on white layer thickness in electrical discharge machining process. Measurement 2019, 131, 694-700. [CrossRef]

10. Tsai, D.C.; Lui, T.S.; Chen, L.H. Effect of graphite nodules on the EDM machinability of ferritic SG cast irons. Mater. Trans. JIM 2000, 41, 293-299. [CrossRef]

11. Grigoriev, S.N.; Kozochkin, M.P.; Kropotkina, E.Y. Okunkova, A.A. Study of wire tool-electrode behavior during electrical discharge machining by vibroacoustic monitoring. Mech. Ind. 2016, 17, 717. [CrossRef]

12. Betsofen, S. X-ray diffraction methods for the evaluation of residual stresses in the surface layers with gradient structure. Mater. Sci. 2006, 42, 367-375. [CrossRef]

13. Markopoulos, A.P.; Papazoglou, E.-L.; Karmiris-Obratański, P. Experimental study on the influence of machining conditions on the quality of electrical discharge machined surfaces of aluminum alloy Al5052. Machines 2020, 8, 12. [CrossRef]

14. Rahman, S.S.; Ashraf, M.Z.I.; Bashar, M.S.; Kamruzzaman, M.; Nurul Amin, A.K.M.; Hossain, M.M. Crystallinity, surface morphology, and chemical composition of the recast layer and rutile-TiO2 formation on Ti-6Al-4V ELI by wire-EDM to enhance biocompatibility. Int. J. Adv. Manuf. Technol. 2017, 93, 3285-3296.

15. Umar Farooq, M.; Pervez Mughal, M.; Ahmed, N.; Ahmad Mufti, N.; Al-Ahmari, A.M.; He, Y. On the investigation of surface integrity of Ti6Al4V ELI using Si-mixed electric discharge machining. Materials 2020, 13, 1549. [CrossRef] [PubMed]

16. Thangaraj, M.; Annamalai, R.; Moiduddin, K.; Alkindi, M.; Ramalingam, S.; Alghamdi, O. Enhancing the surface quality of micro titanium alloy specimen in WEDM process by adopting TGRA-based optimization. Materials 2020, 13, 1440. [CrossRef]

17. Świercz, R.; Oniszczuk-Świercz, D. Investigation of the influence of reduced graphene oxide flakes in the dielectric on surface characteristics and material removal rate in EDM. Materials 2019, 12, 943. [CrossRef]

18. Volosova, M.A.; Okunkova, A.A.; Povolotskiy, D.E.; Podrabinnik, P.A. Study of electrical discharge machining for the parts of nuclear industry usage. Mech. Ind. 2015, 16, 706. [CrossRef]

19. Niamat, M.; Sarfraz, S.; Shehab, E.; Ismail, S.O.; Khalid, Q.S. Experimental characterization of electrical discharge machining of aluminum 6061 T6 alloy using different dielectrics. Arab. J. Sci. Eng. 2019, 44, 8043-8052. [CrossRef]

20. Obrosov, A.; Gulyaev, R.; Zak, A.; Ratzke, M.; Naveed, M.; Dudzinski, W.; Weiß, S. Chemical and morphological characterization of magnetron sputtered at different bias voltages $\mathrm{Cr}-\mathrm{Al}-\mathrm{C}$ coatings. Materials 2017, 10, 156. [CrossRef]

21. Bains, P.S.; Singh, S.; Sidhu, S.S.; Kaur, S.; Ablyaz, T.R. Investigation of surface properties of Al-SiC composites in hybrid electrical discharge machining. In Futuristic Composites, 1st ed.; Sidhu, S., Bains, P., Zitoune, R., Yazdani, M., Eds.; Springer: Singapore, 2018; pp. 181-196.

22. Vozniakovskii, A.A.; Kidalov, S.V.; Kol'tsova, T.S. Development of composite material aluminum-carbon nanotubes with high hardness and controlled thermal conductivity. J. Compos. Mater. 2019, 53, 2959-2965. [CrossRef]

23. Razeghiyadaki, A.; Molardi, C.; Talamona, D.; Perveen, A. Modeling of material removal rate and surface roughness generated during electro-discharge machining. Machines 2019, 7, 47. [CrossRef]

24. Schubert, A.; Zeidler, H.; Hackert-Oschaetzchen, M.; Schneider, J.; Hahm, M. Enhancing micro-EDM using ultrasonic vibration and approaches for machining of nonconducting ceramics. Stroj. Vestn. J. Mech. Eng. 2013, 59, 156-164. 
25. Grigoriev, S.N.; Masterenko, D.A.; Teleshevskii, V.I.; Emelyanov, P.N. Contemporary state and outlook for development of metrological assurance in the machine-building industry. Meas. Tech. 2013, 55, 1311.

26. Grigor'ev, S.N.; Kozochkin, M.P.; Fedorov, S.V.; Porvatov, A.N.; Okun'kova, A.A.; Kozochkin, M. Study of electroerosion processing by vibroacoustic diagnostic methods. Meas. Tech. 2015, 58, 878-884.

27. Volosova, M.A.; Grigor'ev, S.N.; Kuzin, V.V. Effect of titanium nitride coating on stress structural inhomogeneity in oxide-carbide ceramic. Part 4. Action of heat flow. Refract. Ind. Ceram. 2015, 56, 91-96.

28. Volosova, M.A.; Gurin, V.D. Influence of vacuum-plasma nitride coatings on contact processes and a mechanism of wear of working surfaces of high-speed steel cutting tool at interrupted cutting. J. Frict. Wear 2013, 34, 183-189.

29. Fominski, V.Y.; Grigoriev, S.N.; Romanov, R.I.; Volosova, M.A.; Grunin, A.I.; Teterina, G.D. The formation of a hybrid structure from tungsten selenide and oxide plates for a hydrogen-evolution electrocatalyst. Tech. Phys. Lett. 2016, 42, 555-558.

30. Volosova, M.A.; Grigoriev, S.N.; Ostrikov, E.A. Use of laser ablation for formation of discontinuous (discrete) wear-resistant coatings formed on solid carbide cutting tool by electron beam alloying and vacuum-arc deposition. Mech. Ind. 2016, 17, 720.

31. Glaziev, S.Y. The discovery of regularities of change of technological orders in the central economics and mathematics institute of the soviet academy of sciences. Econ. Math. Methods 2018, 54, 17-30.

32. Korotayev, A.V.; Tsirel, S.V. A spectral analysis of world GDP dynamics: Kondratiev waves, Kuznets swings, Juglar and Kitchin cycles in global economic development, and the 2008-2009 economic crisis. Struct. Dyn. 2010, 4, 3-57.

33. Schumpeter, J.; Becker, M.C.; Knudsen, T. The fundamental phenomenon of economic development. Am. J. Econ. Sociol. 2002, 61, 405-437.

34. Perez, C. Technological revolutions and techno-economic paradigms. Camb. J. Econ. 2010, 34, $185-202$.

35. Bobovich, B.B. Glass-fiber reinforced plastics—construction materials of the sixth technological paradigm? Glas. Ceram. 2019, 76, 38-41.

36. Wonglimpiyarat, J. Towards the sixth Kondratieff cycle of nano revolution. Int. J. Nanotechnol. Mol. Comput. 2011, 3, 87-100.

37. Lee, M.; Borom, M.P. Rapid rate sintering of Al2O3-TiC composites for cutting-tool applications. Adv. Ceram. Mater. 1988, 3, 38-44.

38. Gao, L.; Hong, J.S.; Miyamoto, H.; Torre, S.D.D.L. Bending strength and microstructure of Al2O3 ceramics densified by spark plasma sintering. J. Eur. Ceram. Soc. 2000, 20, 2149-2152.

39. Lukashenko, S.V.; Kovtun, A.V.; Dashuk, P.N.; Sokolov, B.N. The Method of Electrical Discharge Machining of Dielectrics. Patent 1,542,715, 10 December 1986.

40. Mohri, N. EDM of advanced ceramics-From finish machining to machining insulating ceramics. CIRP Ann. Manuf. Technol. 1996, 45, 289-296.

41. Lazarenko, B.R.; Lazarenko, N.I. A Method of Working Metals and Other Electro-Conductive Materials and Means for Applying Same. United Kingdom Patent GB637793A, 3 April 1943.

42. Lazarenko, B.R.; Gitlevich, A.E.; Tkachenko, V.N. Certain characteristics of the discharge and plasma flow during the deposition of powdered coatings (Nekotorye Kharakteristiki Razryada I Plazmennogo Potoka Pri Nanesenii Pokrytii Iz Poroshkovykh Materialov). Surf. Eng. Appl. Electrochem. (Elektronnaya Obrabotka Materialov) 1974, 60, 29-31.

43. Lazarenko, B.R.; Mikhailov, V.V.; Gitlevich, A.E.; Verkhoturov, A.D.; Anfimov, I.S. Distribution of elements in surface layers during electric spark alloying [Raspredelenie Elementov V Poverkhnostnykh Sloyakh Pri Elektroiskrovom Legirovanii]. Surf. Eng. Appl. Electrochem. (Elektronnaya Obrabotka Materialov) 1977, 3, 28-33.

44. Lazarenko, B.R.; Duradzhi, V.N.; Bryantsev, I.V. Effect of Incorporating an additional inductance on the characteristics of anode and cathode processes (O Vliyanii Vklyucheniya Dopolnitel'noi Induktivnosti Na Kharakteristiki Anodnogo I Katodnogo Protsessov). Surf. Eng. Appl. Electrochem. (Elektronnaya Obrabotka Materialov) 1979, 5, 8-13.

45. Lazarenko, B.R.; Lazarenko, N.I. Electric spark machining of metals in water and electrolytes. (Elektroiskrovaya Obrabotka Metallov V Vode I Elektrolitakh). Surf. Eng. Appl. Electrochem. (Elektronnaya Obrabotka Materialov) 1980, 1, 5-8. 
46. Tzeng, Y.F.; Lee, C.Y. Effects of powder characteristics on electrodischarge machining efficiency. Int. J. Adv. Manuf. Technol. 2001, 17, 586-592.

47. Ivanov, R.; Hussainova, I.; Aghayan, M.; Drozdova, M.; Perez-Coll, D.; Carvajal Rodriguez, M.A.; Rubio-Marcos, F. Graphene-encapsulated aluminium oxide nanofibers as a novel type of nanofillers for electroconductive ceramics. J. Eur. Ceram. Soc. 2015, 35, 4017. [CrossRef]

48. Liu, J.; Li, J.; Xu, C. Interaction of the cutting tools and the ceramic-reinforced metal matrix composites during micro-machining: A review. CIRP J. Manuf. Sci. Technol. 2004, 7, 55-70.

49. Melnik, Y.A.; Kozochkin, M.P.; Porvatov, A.N.; Okunkova, A.A. On adaptive control for electrical discharge machining using vibroacoustic emission. Technologies 2018, 6, 96. [CrossRef]

50. Baseri, H.; Sadeghian, S. Effects of nanopowder TiO2-mixed dielectric and rotary tool on EDM. Int. J. Adv. Manuf. Technol. 2016, 83, 519-528.

51. Zhang, Y.; Wang, C.; Wang, Y.; Ni, Q.; Ji, L. Geometric Accuracy Improvement by Using Electrochemical Reaming with a Helical Tube Electrode as Post-Processing for EDM. Materials 2019, 12, 3564.

52. Kozochkin, M.P.; Grigor'ev, S.N.; Okun'kova, A.A.; Porvatov, A.N. Monitoring of electric discharge machining by means of acoustic emission. Russ. Eng. Res. 2016, 36, 244-248.

53. Yue, X.; Yang, X.; Tian, J.; He, Z.; Fan, Y. Thermal, mechanical and chemical material removal mechanism of carbon fiber reinforced polymers in electrical discharge machining. Int. J. Mach. Tools Manuf. 2018, 133, 4-17.

54. Zasimchuk, E.; Baskova, O.; Gatsenko, O.; Turchak, T. Universal mechanism of viscoplastic deformation of metallic materials far from thermodynamics equilibrium. J. Mater. Eng. Perform. 2018, 27, 4183-4196.

55. Ehle, L.C.; Schneider, S.; Schwedt, A.; Richter, S.; Klink, A.; Mayer, J. Electron microscopic characterization of surface zones thermo-chemically modified by electrical discharge machining. J. Mater. Process. Tech. 2020, 280, 116596.

56. Faisal, N.; Kumar, K. Optimization of machine process parameters in EDM for EN 31 using evolutionary optimization techniques. Technologies 2018, 6, 54. [CrossRef]

57. Gavrin, V.N.; Kozlova, Y.P.; Veretenkin, E.P.; Logachev, A.V.; Logacheva, A.I.; Lednev, I.S.; Okunkova, A.A. Reactor target from metal chromium for "pure" high-intensive artificial neutrino source. Phys. Part. Nucl. Lett. 2016, 13, 267-273.

58. Porvatov, A.N.; Kozochkin, M.P.; Fedorov, S.V.; Okunkova, A.A. About possibility of vibroacoustic diagnostics of electrical discharge machining and characterization of defects. Mech. Ind. 2015, 16, 707. [CrossRef]

59. Kumar, A.S.; Durai, A.R.; Sornakumar, T. Machinability of hardened steel using alumina-based ceramic cutting tools. Int. J. Refract. Met. Hard Mater. 2003, 21, 109-117.

60. Gevorkyan, E.; Lavrynenko, S.; Rucki, M.; Siemiatkowski, Z.; Kislitsa, M. Ceramic cutting tools out of nanostructured refractory compounds. Int. J. Refract. Met. Hard Mater. 2017, 68, 142-144.

61. Wang, D.; Xue, C.; Cao, Y.; Zhao, J. Fabrication and cutting performance of an Al2O3/TiC/TiN ceramic cutting tool in turning of an ultra-high-strength steel. Int. J. Adv. Manuf. Technol. 2017, 91, 1967-1976.

62. Laine, R.M.; Marchal, J.C.; Sun, H.P.; Pan, X.Q. Nano- $\alpha-\mathrm{Al} 2 \mathrm{O} 3$ by liquid-feed flame spray pyrolysis. Nat. Mater. 2006, 5, 710-712.

63. Kolodiazhnyi, T.; Annino, G.; Spreitzer, M.; Taniguchi, T.; Freer, R.; Azough, F.; Panariello, A.; Fitzpatrick, W. Development of Al2O3-TiO2 composite ceramics for high-power millimeter-wave applications. Acta Mater. 2009, 57, 3402-3409.

64. Evans, A.G. Perspective on the development of high-toughness ceramics. J. Am. Ceram. Soc. 1990, 73, 187-206.

65. Boatemaa, L.; Bosch, M.; Farle, A.-S.; Bei, G.-P.; Van der Zwaag, S.; Sloof, W.G. Autonomous high-temperature healing of surface cracks in Al2O3 containing Ti2AlC particles. J. Am. Ceram. Soc. 2018, 101, 5684-5693.

66. Ercenk, E.; Guven, B.; Yilmaz, S. Crystallization kinetics of machinable glass ceramics produced from volcanic basalt rock. J. Non-Cryst. Solids 2018, 498, 262-271.

67. Song, Q.; Zhang, Z.-H.; Hu, Z.-Y.; Yin, S.-P.; Wang, H.; Wang, H.; Cheng, X.-W. Fully dense B4C ceramics fabricated by spark plasma sintering at relatively low temperature. Mater. Res. Express 2018, 5, 105201. [CrossRef]

68. Li, L.; Pu, S.; Liu, Y.; Zhao, L.; Ma, J.; Li, J. High-purity disperse alpha-Al2O3 nanoparticles synthesized by high-energy ball milling. Adv. Powder Technol. 2018, 29, 2194-2203.

69. Li, L. Effect of cyclic fatigue loading on matrix multiple fracture of fiber-reinforced ceramic-matrix composites. Ceramics 2019, 2, 327-346. 
70. Dassios, K.G.; Matikas, T.E. Assessment of fatigue damage and crack propagation in ceramic matrix composites by infrared thermography. Ceramics 2019, 2, 393-406.

71. Ghouli, S.; Ayatollahi, M.R.; Bushroa, A.R. Fracture characterization of ceria partially stabilized zirconia using the GMTSN criterion. Eng. Fract. Mech. 2018, 199, 647-657.

72. Ighodaro, O.L.; Okoli, O.I. Fracture toughness enhancement for alumina systems: A Review. Int. J. Appl. Ceram. Technol. 2008, 5, 313-323.

73. Szutkowska, M.; Cygan, S.; Podsiadlo, M.; Laszkiewicz-Lukasik, J.; Cyboron, J.; Kalinka, A. Properties of $\mathrm{TiC}$ and TiN Reinforced Alumina-Zirconia Composites Sintered with Spark Plasma Technique. Metals 2019, 9, 1220 .

74. Zheng, G.; Zhao, J.; Gao, Z.; Cao, Q. Cutting performance and wear mechanisms of Sialon-Si3N4graded nano-composite ceramic cutting tools. Int. J. Adv. Manuf. Technol. 2012, 58, 19-28.

75. Grigoriev, S.N.; Metel, A.S.; Melnik, Y.A.; Volosova, M.A. Equipment and Technology for Combined Ion-Plasma Strengthening of Cutting Tools. Machines 2018, 6, 58. [CrossRef]

76. Orlova, A.I.; Ojovan, M.I. Ceramic mineral waste-forms for nuclear waste immobilization. Materials 2019, $12,2638$.

77. Kachaev, A.A.; Grashchenkov, D.V.; Lebedeva, Y.E.; Solntsev, S.S.; Khasanov, O.L. Optically transparent ceramic (review). Glass. Ceram. 2016, 73, 117-123.

78. Lyamina, G.V.; Ilela, A.E.; Dvilis, E.S.; Petyukevich, M.A.; Tolkachev, O.S. Medical ceramics from powders of the system Al2O3-ZrO2-Y2O3 obtained on an installation of nanospray drying. Nanotechnol. Russ. 2018, 13, 337-343.

79. Gommeringer, A.; Kern, F. Mechanical properties and electrical discharge machinability of alumina- $10 \mathrm{vol} \%$ zirconia-28 vol\% titanium nitride composites. Ceramics 2020, 3, 199-209.

80. Boulesteix, R.; Chevarin, C.; Belon, R.; Maître, A.; Cochain, L.; Sallé, C. Manufacturing of large size and highly transparent $\mathrm{Nd}$ : YAG ceramics by pressure slip-casting and post-sintering by HIP: An experimental and simulation study. Materials 2020, 13, 2199.

81. Maksimov, R.N.; Khrustov, V.R.; Shitov, V.A.; Yurovskikh, A.S. Effect of the thermal shrinkage behavior of $\mathrm{Yb}: \mathrm{Lu} 2 \mathrm{O} 3$ nanopowder compacts on the structural and optical characteristics of ceramics. Inorg. Mater. 2019, 55, 634-639.

82. Grishaev, V.V.; Tostanovskii, V.I. Properties of oxide structural ceramics made from mechanically milled powders. Refract. Ind. Ceram. 1993, 34, 98-102.

83. Annenkov, Y.M.; Ivanov, V.V.; Ivashutenko, A.S.I.; Kondratyuk, A.A.; Sivkov, A.A. Efficiency of different compaction methods for corundum-zirconia powders. Refract. Ind. Ceram. 2008, 49, 461-465.

84. Gavrilkin, S.M.; Kopaneva, L.I.; Batsanov, S.S. Anomalous phase transition in shock-compressed PbO. Combust. Explos. Shock Waves 2003, 39, 723-726.

85. Grigoriev, S.N.; Dmitriev, A.M.; Korobova, N.V.; Fedorov, S.V. A cold-pressing method combining axial and shear flow of powder compaction to produce high-density iron parts. Technologies 2019, 7, 70. [CrossRef]

86. Lazar, A.; Kosmač, T.; Zavašnik, J.; Abram, A.; Kocjan, A. TiN-nanoparticulate-reinforced ZrO2 for electrical discharge machining. Materials 2019, 12, 2789. [CrossRef]

87. Morozova, L.V.; Kalinina, M.V.; Drozdova, I.A.; Shilova, O.A. Preparation and characterization of nanoceramics for solid oxide fuel cells. Inorg. Mater. 2018, 54, 79-86.

88. Khasanov, O.L.; Pokholkov, Y.P.; Sokolov, V.M.; Dvilis, É.S.; Slosman, A.I.; Matrenin, S.V. Ultrasonic compacting of zirconium ceramics from ultradispersed powders. Glass. Ceram. 1995, 52, 177-180.

89. Gadow, R.; Kern, F. Pressureless sintering of injection molded zirconia toughened alumina nanocomposites. J. Ceram. Soc. Jpn. 2006, 114, 958-962.

90. Morozova, L.V.; Kovalko, N.Y.; Kalinina, M.V.; Shilova, O.A. Production of chemically pure zirconia-based nanoceramics in the ZrO2(Y2O3)-Al2O3 system for restorative dentistry. Theor. Found. Chem. Eng. 2019, 53, 848-854.

91. Smirnov, V.V.; Smirnov, S.V.; Obolkina, T.O.; Antonova, O.S.; Goldberg, M.A.; Barinov, S.M. The influence of manganese oxide on the sintering and properties of the eutectic ceramics of the $\mathrm{ZrO} 2-\mathrm{Al} 2 \mathrm{O} 3-\mathrm{SiO} 2$ system. Dokl. Chem. 2019, 486, 160-163.

92. Morozova, L.V. Mechanochemical Activation of precursor powders for the preparation of dense $\mathrm{Al} 2 \mathrm{O} 3-\mathrm{ZrO} 2$ <Y2O3> nanoceramics. Inorg. Mater. 2019, 55, 295-301. 
93. Novikov, Y.N. The FLASH Memory Based on Silicon Nitride (SONOS), 1st ed.; Nova Publisher: New York, NY, USA, 2011; pp. 35-66.

94. Roman, O.V.; Kovalevskaya, A.V.; Fomikhina, I.V.; Grigoriev, S.V. Development of carbide and nitride ceramics of increased strength (Razrabotka karbidnoy i nitridnoy keramiki povyshennoy prochnosti). Lit'e Metall. 2005, 4, 157-162.

95. Podbolotov, K.B.; Volochko, A.T.; Khort, N.A.; Gusarov, S.V. Refractory materials based on secondary resources and phosphate compounds. Refract. Ind. Ceram. 2019, 59, 579-582.

96. Podbolotov, K.B.; Dyatlova, E.M.; Volochko, A.T. Synthesis and reinforcement of heat-resistant cordierite-mullite ceramic structure with introduction of a fiber filler. Refract. Ind. Ceram. 2016, 57, 151-154.

97. Volochko, A.T.; Podbolotov, K.B.; Dyatlova, E.M. Refractory and Infusible Ceramics (Ogneupornye I Tugoplavkie Keramicheskie Materialy), 1st ed.; Belorus. Nauka: Minsk, Belarus, 2013; pp. 79-82.

98. Makarov, A.V.; Skorynina, P.A.; Volkova, E.G.; Osintseva, A.L. Effect of heating on the structure, phase composition, and micromechanical properties of the metastable austenitic steel strengthened by nanostructuring frictional treatment. Phys. Met. Met. 2018, 119, 1196-1203.

99. Borisov, M.; Lobanov, D.; Yanyushkin, A.; Skeeba, V. Investigation of the process of automatic control of current polarity reversal in the conditions of hybrid technology of electrochemical processing of corrosion-resistant steels. Obrab. Met.-Met. Work. Mater. Sci. 2020, 22, 6-15.

100. Ojha, N.; Zeller, F.; Mueller, C.; Reinecke, H. The effect of the electrical discharge machining process on the material properties of nonconductive ceramics. J. Micro Nano-Manuf. 2016, 4, 1-5.

101. Kumar, R.; Chaubey, A.K.; Maity, T.; Prashanth, K.G. Mechanical and tribological properties of Al2O3-TiC composite fabricated by spark plasma sintering process with metallic (Ni, Nb) binders. Metals 2018, 8, 50. [CrossRef]

102. Godin, N.; Reynaud, P.; R'Mili, M.; Fantozzi, G. Identification of a critical time with acoustic emission monitoring during static fatigue tests on ceramic matrix composites: Towards lifetime prediction. Appl. Sci. 2016, 6, 43. [CrossRef]

103. Grigoriev, S.N.; Krapostin, A.A. Multilayer composite nanoscale coatings as a method to increase reliability and tool life of cutting tools made of mixed ceramic Al2O3-TiC. Mech. Ind. 2016, 17, 704.

104. Volosova, M.; Grigoriev, S.; Metel, A.; Shein, A. The Role of Thin-Film Vacuum-Plasma Coatings and Their Influence on the Efficiency of Ceramic Cutting Inserts. Coatings 2018, 8, 287. [CrossRef]

105. Khodaee, A.; Melander, A. Numerical and experimental analysis of the gear size influence on density variations and distortions during the manufacturing of PM gears with an innovative powder processing route incorporating HIP. J. Manuf. Mater. Process. 2018, 2, 49. [CrossRef]

106. Jayalakshmi, S.; Singh, R.A.; Gupta, M. Metallic glasses as potential reinforcements in $\mathrm{Al}$ and $\mathrm{Mg}$ matrices: A review. Technologies 2018, 6, 40.

107. Balog, M.; Ibrahim, A.M.H.; Krizik, P.; Bajana, O.; Klimova, A.; Catic, A.; Schauperl, Z. Bioactive Ti plus $\mathrm{Mg}$ composites fabricated by powder metallurgy: The relation between the microstructure and mechanical properties. J. Mech. Behav. Biomed. 2019, 90, 45-53.

108. Nicoara, M.; Buzdugan, D.; Locovei, C.; Bena, T.; Stoica, M. About thermostability of biocompatible Ti-Zr-Ag-Pd-Sn amorphous alloys. J. Therm. Anal. Calorim. 2018, 133, 189-197.

109. Veronesi, P.; Rosa, R.; Colombini, E.; Leonelli, C. Microwave-Assisted preparation of high entropy alloys. Technologies 2015, 3, 182-197.

110. Sezer, N.; Evis, Z.; Kayhan, S.M.; Tahmasebifar, A.; Koc, M. Review of magnesium-based biomaterials and their applications. J. Magnes. Alloy. 2018, 6, 23-43.

111. Xanthopoulou, G.; Thoda, O.; Boukos, N.; Krishnamurthy, S.; Dey, A.; Roslyakov, S.; Vekinis, G.; Chroneos, A.; Levashov, E. Effects of precursor concentration in solvent and nanomaterials room temperature aging on the growth morphology and surface characteristics of ni-nio nanocatalysts produced by dendrites combustion during SCS. Appl. Sci. 2019, 9, 4925. [CrossRef]

112. Volykhov, A.A.; Sanchez-Barriga, J.; Sirotina, A.P.; Neudachina, V.S.; Frolov, A.S.; Gerber, E.A.; Kataev, E.Y.; Senkovsky, B.; Khmelevsky, N.O.; Aksenenko, A.Y.; et al. Rapid surface oxidation of Sb2Te3 as indication for a universal trend in the chemical reactivity of tetradymite topological insulators. Chem. Mater. 2016, 28, $8916-8923$. 
113. Grigoriev, S.N.; Kozochkin, M.P.; Sabirov, F.S.; Kutin, A.A. Diagnostic systems as basis for technological improvement. Proc. CIRP 2012, 1, 599-604.

114. Ferreira, S.C.; Conde, A.; Arenas, M.A.; Rocha, L.A.; Velhinho, A. Anodization mechanism on sic nanoparticle reinforced al matrix composites produced by power metallurgy. Materials 2014, 7, 8151-8167.

115. Xu, C.; Liu, F.; Huang, L.; Jiang, L. Dependence of creep performance and microstructure evolution on solution cooling rate in a polycrystalline superalloy. Metals 2018, 8, 4. [CrossRef]

116. Iankov, R. Finite element simulation of powder metal compaction processes in container with several punches. Nato Sci. Ser. 2001, 176, 169-180.

117. Sobol, O.V.; Andreev, A.A.; Grigoriev, S.N.; Gorban', V.F.; Volosova, M.A.; Aleshin, S.V.; Stolbovoy, V.A. Physical characteristics, structure and stress state of vacuum-arc tin coating, deposition on the substrate when applying high-voltage pulse during the deposition. Probl. Atom. Sci. Tech. 2011, 4, 174-177.

118. Loh, N.J.; Simao, L.; Jiusti, J.; De Noni, A., Jr.; Montedo, O.R.K. Effect of temperature and holding time on the densification of alumina obtained by two-step sintering. Ceram. Int. 2017, 43, 8269-8275.

119. Tamura, Y.; Moshtaghioun, B.M.; Gomez-Garcia, D.; Rodríguez, A.D. Spark plasma sintering of fine-grained alumina ceramics reinforced with alumina whiskers. Ceram. Int. 2017, 43, 658-663.

120. Jin, Y.; Han, M.-K.; Kim, S.-J. Na-Doping effects on thermoelectric properties of Cu2-xSe nanoplates. Appl. Sci. 2018, 8, 12. [CrossRef]

121. Ning, J.; Wu, D.; Zhao, D. Synthesis and thermoelectric properties of TiO2/Cu2SnSe3 composites. Appl. Sci. 2017, 7, 1043.

122. Alleno, E. Review of the thermoelectric properties in nanostructured Fe2Val. Metals 2018, 8, 864. [CrossRef]

123. Zhang, H.; Zhang, L.; Liu, X.; Chen, Q.; Xu, Y. Effect of Zr addition on the microstructure and mechanical properties of CoCrFeNiMn high-entropy alloy synthesized by spark plasma sintering. Entropy 2018, $20,810$. [CrossRef]

124. Viswanathan, V.; Laha, T.; Balani, K.; Agarwal, A.; Seal, S. Challenges and advances in nanocomposite processing techniques. Mater. Sci. Eng. R 2006, 54, 121-285.

125. Wang, L.; Zhang, J.; Jiang, W. Recent development in reactive synthesis of nanostructured bulk materials by spark plasma sintering. Int. J. Refract. Met. Hard Mater. 2013, 39, 103-112.

126. Zhang, Y.F.; Wang, L.J.; Jiang, W.; Chen, L.-D. Microstructure and properties of Al2O3-TiC composites fabricated by combination of high-energy ball milling and spark plasma sintering (SPS). J. Inorg. Mater. 2005, 20, 1445.

127. Oraei, M.; Mostaan, H.; Rafiei, M.; Abbasian, A.R.; Zarezadeh, M. Investigation into microstructural evolutions, mechanical properties and thermal analysis of $\mathrm{Al}(\mathrm{Zn}) / \mathrm{Al} 2 \mathrm{O} 3$ nano-composite fabricated by mechanical milling and SPS method. Mater. Res. Express 2019, 6, 0865g9.

128. Moriceau, J.; Houizot, P.; Pasturel, M.; Guizouarn, T.; Rouxel, T. A magnetic glass matrix (ZnO-BaO-B2O3) particulate (Fe3O4) nanocomposite obtained by SPS. J. Non Cryst. Solids 2019, 514, 116-121.

129. Fedorov, S.V.; Pavlov, M.D.; Okunkova, A.A. Effect of structural and phase transformations in alloyed subsurface layer of hard-alloy tools on their wear resistance during cutting of high-temperature alloys. J. Frict. Wear 2013, 34, 190-198.

130. Chaudhary, T.; Siddiquee, A.N.; Chanda, A.K. Effect of wire tension on different output responses during wire electric discharge machining on AISI 304 stainless steel. Def. Technol. 2019, 15, 541. [CrossRef]

131. Maradia, U.; Filisetti, E.; Boccadoro, M.; Roten, M.; Dutoit, J.-M.; Hengsberger, S. Increasing the injection moulding productivity through EDM surface modulation. Proc. CIRP 2018, 68, 58. [CrossRef]

132. Uhlmann, E.; Oberschmidt, D.; Bolz, R. Application of micro structured, boron doped CVD-diamond as mu EDM tool electrodes. Proc. CIRP 2018, 68, 649.

133. Sahu, A.K.; Chatterjee, S.; Nayak, P.K.; Mahapatra, S.S. Study on effect of tool electrodes on surface finish during electrical discharge machining of Nitinol. IOP Conf. Ser. Mater. Sci. Eng. 2018, 338, 012033.

134. Prathipati, R.P.; Devuri, V.; Cheepu, M.; Gudimetla, K.; Kiran, R.U. Machining of AISI D2 tool steel with multiple hole electrodes by EDM process. IOP Conf. Ser. Mater. Sci. Eng. 2018, 330, 012067.

135. Trung, K.H. Development of a WEDM system with high machining efficiency. Int. Conf. Syst. Sci. Eng. 2017, 397-399. [CrossRef]

136. Wu, H.; Wang, T.; Wang, J. Research on discharge state detection of finishing in high-speed wire electrical discharge machine. Int. J. Adv. Manuf. Technol. 2019, 103, 2301. 
137. Takale, A.; Chougule, N. Optimization of process parameters of wire electro discharge machining for Ti49.4Ni50.6 shape memory alloys using the Taguchi technique. Int. J. Struct. Integr. 2019, 10, 548. [CrossRef]

138. Reshetnikov, S.; Kurzina, I.; Livanova, A.; Meshcheryakov, E.; Isupova, L. Effect of Li, Na and K modification of alumina on its physical and chemical properties and water adsorption ability. Materials 2019, 12, 4212. [CrossRef]

139. Konishcheva, M.V.; Svintsitskiy, D.A.; Potemkin, D.I.; Rogozhnikov, V.N.; Sobyanin, V.A.; Snytnikov, P.V. Catalytic performance and characterization of highly efficient composite $\mathrm{Ni}(\mathrm{Cl}-\mathrm{x}) / \mathrm{CeO} 2 / \mathrm{eta}-\mathrm{Al} 2 \mathrm{O} 3 / \mathrm{FeCrAl}$ wire mesh catalysts for preferential CO methanation. Chemistryselect 2020, 5, 1228-1234.

140. Kholodnaya, G.; Sazonov, R.; Ponomarev, D.; Zhirkov, I. Pulsed plasma chemical synthesis of carbon-containing titanium and silicon oxide based nanocomposite. Radiat. Phys. Chem. 2018, 144, 132-137.

141. Matveev, V.A.; Kalinnikov, V.T.; Zakharov, V.I.; Maiorov, D.V. Investigation of an effect exerted by methods of production of chromium(III) oxides-hydroxides on their physicochemical properties. Russ. J. Appl. Chem. 2011, 84, 1524-1528.

142. Yang, J.; Liu, Y.; Deng, J.; Zhao, X.T.; Zhang, K.F.; Han, Z.; Dai, H.X. AgAuPd/meso-Co3O4: High-performance catalysts for methanol oxidation. Chin. J. Catal. 2019, 40, 837-848.

143. Shiryaev, M.A.; Jin, Y.J.; Bong, H.C.; Baranov, A. ZnO nanoparticle modification by polyethylenimine for biomolecule conjugation. Nanotechnol. Russ. 2017, 12, 613-619.

144. Gavelova, P.; Halodova, P.; Namburi, H.K.; Prokupkova, I.A.; Miklos, M.; Krejci, J. From micro to nano: Material characterization methods for testing of nuclear core and structural materials. J. Nucl. Eng. Radiat. Sci. 2019, 5, 030917. [CrossRef]

145. Olenin, A.Y.; Lisichkin, G.V. Surface-modified oxide nanoparticles: Synthesis and application. Russ. J. Gen. Chem. 2019, 89, 1451-1476.

146. Voroshilov, Y.V.; Gorshkova, L.V.; Popova, A.M.; Fedorov, T.F. Ternary systems Ti-Zr-C and Ti-Hf-C. Sov. Powder Met. 1967, 6, 403-405.

147. Bulienkov, N.A.; Zheligovskaya, E.A.; Chernogorova, O.P.; Drozdova, E.I.; Ushakova, I.N.; Ekimov, E.A. Nonequilibrium diamond growth during the high-temperature high-pressure synthesis of a composite material made of a mixture of cobalt and fullerene powders. Russ. Met. 2018, 1, 35-41.

148. Titkov, Y.; Berdnikova, O.; Tyurin, Y.; Kolisnichenko, O.; Polovetskiy, Y.; Kushnaryova, O. Effect of structure on the properties of composite Cr3C2 + NiCr coatings. Springer Proc. Phys. 2020, 240, 151-159.

149. Zotti, G.; Cattarin, S.; Mengoli, G.; Fleischmann, M.; Peter, L.M. Photoelectrochemistry of copper(I) acetylide films electrodeposited onto copper electrodes. J. Electroanal. Chem. 1986, 200, 341-351.

150. Denisov, E.T.; Sarkisov, O.M.; Likhtenshtein, G.I. Chemical Kinetics: Fundamentals and Recent Developments, 1st ed.; Elsevier Science: Amsterdam, The Netherlands, 2008; pp. 472-486.

151. Zirconium (Zirconiy). Chemical Encyclopedia (Khimicheskaya Enciklopediya), 1st ed.; Zefirov, N.S., Kulov, N.N., Eds.; Great Russian Encyclopedia (Bolshaya Rossiyskaya Enciklopediya): Moscow, Russia, 1998; Volume 5.

152. Li, X.F.; Hu, Z.Y.; Huang, B. Phase diagram and superconductivity of compressed zirconium hydrides. Phys. Chem. Chem. Phys. 2017, 19, 3538-3543. [PubMed]

153. Sukhushina, I.S. Phase transitions of the $\mathrm{ZrNiH} x$ hydride. Russ. J. Phys. Chem. A 2007, 81, 1595-1600.

154. Besedin, D.V.; Ustynyuk, L.Y.; Ustynyuk, Y.A.; Lunin, V.V. Hydrogenolysis and hydroisomerization of neopentane on titanium and zirconium hydrides stabilized on the surface of $\mathrm{SiO} 2$ : A theoretical study by density functional theory. Russ. J. Phys. Chem. A 2008, 82, 193-200.

155. Grigoriev, S.; Kozochkin, M.; Porvatov, A.; HtuM, T.; Zhavoronsky, P.; Jiang, X.; Pivkin, P. Dynamic model of electrical discharge machining and algorithm of extreme control through acoustic signal. EPJ Web. Conf. 2019, 224, 05002. [CrossRef]

156. Grigoriev, S.N.; Fedorov, S.V.; Hamdy, K. Materials, properties, manufacturing methods and cutting performance of innovative ceramic cutting tools-A review. Manuf. Rev. 2019, 6, 19.

157. Fedotov, P.S.; Ermolin, M.S.; Karandashev, V.K.; Ladonin, D.V. Characterization of size, morphology and elemental composition of nano-, submicron, and micron particles of street dust separated using field-flow fractionation in a rotating coiled column. Talanta 2014, 130, 1-7.

158. Makarova, O.V.; Palatnikov, M.N.; Biryukova, I.V.; Sidorov, N.V. Impact of a dopant impurity electronic structure on physical properties, defect structure, and features of lithium niobate doping technology. Tech. Phys. 2019, 64, 1872-1878. 
159. Ikim, M.I.; Spiridonova, E.Y.; Belysheva, T.V.; Gromov, V.F.; Gerasimov, G.N.; Trakhtenberg, L.I. Structural properties of metal oxide nanocomposites: Effect of preparation method. Russ. J. Phys. Chem. B 2016, 10, 543-546.

160. Brauer, G.; Baudler, M.; Fehér, F. Handbuch der Präparativen Anorganischen Chemie, 3rd ed.; Enke: Stuttgart, Germany, 1978.

161. Kovtunenko, P.V.; Nesterova, I.L. Tin oxides. In Chemical Encyclopedia (Khimicheskaya Enciklopediya), 1st ed.; Knunyants, I.L., Ed.; Great Russian Encyclopedia (Bolshaya Rossiyskaya Enciklopediya): Moscow, Russia, 1992; Volume 3, pp. 515-548.

162. Gommeringer, A.; Kern, F.; Gadow, R. Enhanced mechanical properties in ED-Machinable Zirconia-Tungsten carbide composites with Yttria-Neodymia Co-Stabilized zirconia matrix. Ceramics 2018, 1, $26-37$.

163. Samsonov, G.V.; Vinitskiy, I.M. Refractory Compounds (Handbook) (Tugoplavkie Soedineniya (Spravochnik)), 1st ed.; Mettalurgiya: Moscow, Russia, 1976; p. 560.

(C) 2020 by the authors. Licensee MDPI, Basel, Switzerland. This article is an open access article distributed under the terms and conditions of the Creative Commons Attribution (CC BY) license (http://creativecommons.org/licenses/by/4.0/). 